Original Article

\title{
A threefold approach including quantum chemical, molecular docking and molecular dynamic studies to explore the natural compounds from Centaurea jacea as the potential inhibitors for COVID-19
}

\author{
Uma abordagem tríplice incluindo química quântica, docking molecular e estudos \\ dinâmicos moleculares para explorar os compostos naturais de Centaurea jacea como \\ inibidores potenciais para Covid-19
}

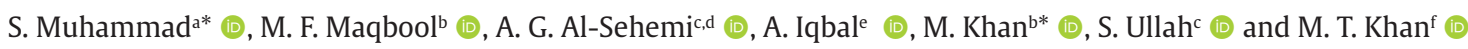 \\ aKing Khalid University, College of Science, Department of Physics, Abha, Saudi Arabia \\ bUniversity of the Punjab, Department of Zoology, Quaid-e-Azam Campus, Lahore, Pakistan \\ 'King Khalid University, College of Science, Department of Chemistry, Abha, Saudi Arabia \\ ${ }^{\mathrm{d} K i n g}$ Khalid University, Research Center for Advanced Material Science - RCAMS, Abha, Saudi Arabia \\ eUniversity of Veterinary and Animal Sciences, Department of Wildlife and Ecology, Lahore, Pakistan \\ 'The University of Lahore, Institute of Molecular Biology and Biotechnology - IMBB, Lahore, Pakistan
}

\begin{abstract}
In the current report, we studied the possible inhibitors of COVID-19 from bioactive constituents of Centaurea jacea using a threefold approach consisting of quantum chemical, molecular docking and molecular dynamic techniques. Centaurea jacea is a perennial herb often used in folk medicines of dermatological complaints and fever. Moreover, anticancer, antioxidant, antibacterial and antiviral properties of its bioactive compounds are also reported. The $\mathrm{M}^{\text {pro }}$ (Main proteases) was docked with different compounds of Centaurea jacea through molecular docking. All the studied compounds including apigenin, axillarin, Centaureidin, Cirsiliol, Eupatorin and Isokaempferide, show suitable binding affinities to the binding site of SARS-CoV-2 main protease with their binding energies $-6.7 \mathrm{kcal} /$ $\mathrm{mol},-7.4 \mathrm{kcal} / \mathrm{mol},-7.0 \mathrm{kcal} / \mathrm{mol},-5.8 \mathrm{kcal} / \mathrm{mol},-6.2 \mathrm{kcal} / \mathrm{mol}$ and $-6.8 \mathrm{kcal} / \mathrm{mol}$, respectively. Among all studied compounds, axillarin was found to have maximum inhibitor efficiency followed by Centaureidin, Isokaempferide, Apigenin, Eupatorin and Cirsiliol. Our results suggested that axillarin binds with the most crucial catalytic residues CYS145 and HIS41 of the $\mathrm{M}^{\text {pro }}$, moreover axillarin shows 5 hydrogen bond interactions and 5 hydrophobic interactions with various residues of $\mathrm{M}^{\text {pro. }}$. Furthermore, the molecular dynamic calculations over $60 \mathrm{~ns}\left(6 \times 10^{6}\right.$ femtosecond) time scale also shown significant insights into the binding effects of axillarin with $\mathrm{M}^{\text {pro }}$ of SARS-CoV-2 by imitating protein like aqueous environment. From molecular dynamic calculations, the RMSD and RMSF computations indicate the stability and dynamics of the best docked complex in aqueous environment. The ADME properties and toxicity prediction analysis of axillarin also recommended it as safe drug candidate. Further, in vivo and in vitro investigations are essential to ensure the anti SARS-CoV-2 activity of all bioactive compounds particularly axillarin to encourage preventive use of Centaurea jacea against COVID-19 infections.
\end{abstract}

Keywords: COVID-19, Apigenin, Centaurea jacea, quantum chemistry, molecular docking, molecular dynamics.

\begin{abstract}
Resumo
No presente relatório, estudamos os possíveis inibidores de Covid-19 de constituintes bioativos de Centaurea jacea usando uma abordagem tripla que consiste em técnicas de química quântica, docking molecular e dinâmica molecular. Centaurea jacea é uma erva perene frequentemente usada em remédios populares de doenças dermatológicas e febre. Além disso, as propriedades anticâncer, antioxidante, antibacteriana e antiviral de seus compostos bioativos também são relatadas. A Mpro (proteases principais) foi acoplada a diferentes compostos de Centaurea jacea por meio de docking molecular. Todos os compostos estudados, incluindo apigenina, axilarina, Centaureidina, Cirsiliol, Eupatorina e Isokaempferide, mostram afinidades de ligação adequadas ao sítio de ligação da protease principal SARS-CoV-2 com suas energias de ligação -6,7 kcal / mol, -7,4 kcal / mol, - 7,0 kcal / mol, -5,8 $\mathrm{kcal} / \mathrm{mol},-6,2 \mathrm{kcal} / \mathrm{mol} \mathrm{e}-6,8 \mathrm{kcal} / \mathrm{mol}$, respectivamente. Dentre todos os compostos estudados, a axilarina apresentou eficiência máxima de inibidor, seguida pela Centaureidina, Isokaempferida, Apigenina, Eupatorina e Cirsiliol. Nossos resultados sugeriram que a axilarina se liga aos resíduos catalíticos mais cruciais CYS145 e
\end{abstract}

*e-mail: mshabbir@kku.edu.sa; khan_zoologist@ymail.com

Received: January 15, 2021 - Accepted: April 26, 2021

This is an Open Access article distributed under the terms of the Creative Commons Attribution License, which permits unrestricted use, distribution, and reproduction in any medium, provided the original work is properly cited. 
HIS41 do Mpro, além disso a axilarina mostra 5 interações de ligações de hidrogênio e 5 interações hidrofóbicas com vários resíduos de Mpro. Além disso, os cálculos de dinâmica molecular em uma escala de tempo de 60 ns (6 $\times 106$ femtossegundos) também mostraram percepções significativas sobre os efeitos de ligação da axilarina com Mpro de SARS-CoV-2 por imitação de proteínas como o ambiente aquoso. A partir de cálculos de dinâmica molecular, os cálculos RMSD e RMSF indicam a estabilidade e dinâmica do melhor complexo ancorado em ambiente aquoso. As propriedades ADME e a análise de previsão de toxicidade da axilarina também a recomendaram como um candidato a medicamento seguro. Além disso, as investigações in vivo e in vitro são essenciais para garantir a atividade anti-SARS-CoV-2 de todos os compostos bioativos, particularmente a axilarina, para encorajar o uso preventivo de Centaurea jacea contra infecções por Covid-19.

Palavras-chave: Covid-19, Apigenina, Centaurea jacea, química quântica, docking molecular, dinâmica molecular.

\section{Introduction}

Viral infections are continued to emerge and symbolize a major problem to public health. In last 20 years, numerous viral epidemics such as the SARS-CoV (severe acute respiratory syndrome coronavirus) in 2002 to 2003, H1N1 pandemic in 2009 and MERS-CoV (Middle East respiratory syndrome coronavirus) was first discovered in Saudi Arabia in 2012, have been reported (Perlman and Netland, 2009; Chan et al., 2013). Previous studies have described that CoVs (coronaviruses) are an etiologic agent of various infections especially respiratory and digestive disorders in mammals, reptiles, avian species and humans (Malik et al., 2020). In the last weeks of 2019, a viral infection COVID-19 caused by a novel virus named as SARSCoV-2 (severe acute respiratory syndrome-coronavirus 2), a new strain of CoVs has been reported in Wuhan, China and spread rapidly throughout the whole world (Wu et al., 2020). SARS-Cov-2 has been identified as an enveloped, non-segmented RNA virus with $29.5 \mathrm{~kb}$ genome (Adem et al., 2020). Genome sequencing of SARS-CoV-2 showed that SARS-CoV-2 is $96.2 \%$ identical to a bat CoV and the RNA genome of SARS-CoV-2 is 79.5\% identical with the RNA genome of SARS-CoV (Lu et al., 2020; Wu et al., 2020; Zhou et al., 2020).

A recent report of $\mathrm{WHO}$ described that epidemic COVID 19 increases rapidly to more than 216 countries, till 03 April 2021, worldwide 129,215,179 cases and $2,820,098$ deaths were reported due to COVID-19 (WHO, 2021). Fast spreading rate and no specific antiviral drug for COVID-19 are few major reasons for such outspread of this pandemic. Currently no specific antiviral drugs or vaccines are available for the remedy of COVID-19. However, recent research suggested that cotreatment of COVID-19 patients with certain previously used antiviral drugs can yield optimistic results (Chang et al., 2020). In emergency situations combination of Lopinavir/ Ritonavir (HIV drugs) and $\alpha$-interferon has been used for the treatment of COVID-19 patients, but therapeutic effects remain very restricted and there can be side effects too (Cao et al., 2020). Other described antiviral compounds for human CoVs include neuraminidase inhibitors, nucleoside analogues, remdesivir, tenofovir disoproxil, umifenovir (arbidol) and lamivudine (Lu et al., 2020). In this need of hour specific targeted anti-SARS-CoV-2 drugs with safety and efficacy are urgently needed.

In some recent studies, Chinese scientists have successfully crystallized the $\mathrm{M}^{\text {pro }}$ (Main Protease) also called 3CLpro (chymotrypsin-like protease) from SARS-CoV-2. Previous studies have been demonstrated that $\mathrm{M}^{\text {pro }}$ can be a possible drug target for the inhibition of replication of
SARS-CoV-2 (Jin et al., 2020; Xu et al., 2020). The $\mathrm{M}^{\text {pro }}$ is a key enzyme of SARS CoV-2 with molecular mass of $33796.8 \mathrm{Da}$ and plays a pivotal role in processing of two polyproteins pp1a and pp1ab into 16 NSPS (non-structural proteins). These NSPS further involve in the synthesis of subgenomic RNAs, these RNAs encode for accessory proteins and four different structural proteins (envelope (E), membrane (M), spike (S), and nucleocapsid (N) proteins). Therefore $\mathrm{M}^{\text {pro, }}$, plays a vital role in the proteolytic maturation and life cycle of SARS CoV-2 (Ramajayam et al., 2011, Ren et al., 2013). Thus, inhibition of $\mathrm{M}^{\text {pro }}$ can be a potential target for the inhibition of SARS CoV-2 life cycle at transcription or translation phase. Moreover, there is no homolog of $\mathrm{M}^{\text {pro }}$ in human genome thus inhibitors of $\mathrm{M}^{\text {pro }}$ will be safe for human (Hayden et al., 2003, Yang et al., 2005) which makes it a supreme antiviral drug target (Dai et al., 2020, Zhang et al., 2020). Now a day computational biology is playing a key role in drug discovery. Molecular docking has been used to check the interactions of ligand (drug) with the binding sites of targeted protein (receptor) (McConkey et al., 2002). It deals with all possible factors involved in drug discovery such as identification of hit compound, optimization of most appropriate molecule and virtual screening (Jorgensen, 2004, Kitchen et al., 2004). Moreover, in silico studies has proved to be very useful in drug discovery in saving resources in terms of time as well as money (Murgueitio et al., 2012). Besides this, in silico studies increases the potential to discover new therapeutic drugs while reducing extensive lab work. Nonetheless, these studies use with care and reported drug targets should test in lab experiments to get benefit of in silico studies.

Designing drugs with maximum selectivity to the target molecule is the main idea of drug discovery (Gertsch, 2011). Medicinal plants are well known among the key sources to provide new pharmaceuticals with maximum selectivity (Balunas and Kinghorn, 2005; Chiarello, 1995). Herbal medicines have a number of advantages over modern synthetic drugs, including fewer side effects, affordability, maximum selectivity with the receptor and cost effectiveness encouraging the discovery of plant based drugs (Chakraborty, 2018; Sharifi-Rad et al., 2018). Plants produce different types of secondary metabolites such as phenols, flavonoids, and alkaloids. Plants may synthesize these metabolites for growth or therapeutic purposes (Salehi et al., 2018; Chakraborty, 2018, Kumar et al., 2020). Moreover, different plants such as Centaurea aegyptiaca, Centaurea alba etc. have already been investigated due to their antiviral effects (Bakr et al., 2016; Politeo et al., 2019). Centaurea jacea commonly known as brown knapweed is a perennial herb of family Asteraceae. Sporadically it has 
been used in different folk medicines for the treatment of dermatological complaints and fever. Its chloroform extract contains different secondary metabolites such as centaureidin, isokaempferide, axillarin, eupatorin, hispidulin, apigenin and cirsiliol (Forgo et al., 2012). Secondary metabolites of Centaurea jacea are bioactive molecules and used in folk medicines for centuries due to their anti-inflammatory, antioxidant, antiviral and antibacterial activities (Yan et al., 2017). Thus, in the present study, we have studied different bioactive molecules of Centaurea jacea against $\mathrm{M}^{\mathrm{pro}}$ by in silico molecular docking study. We plan not only to disclose the most effective bioactive compound of Centaurea jacea as a potent inhibitor of $\mathrm{M}^{\text {pro }}$ but also explore several structure-activity relations by studying intermolecular interactions between potent inhibitors and of $\mathrm{M}^{\mathrm{pro}}$ protein.

\section{Computational Methods}

AutoDock Vina (ADV) was used to perform all the docking analysis because (a) ADV offers more accuracy in analyzing protein-ligand interaction as compared to AutoDock 4.2 (b) it takes shorter running time due to its several core processors (c) ADV provides more accuracy for ligand analyzing more than twenty rotatable bonds (Narkhede et al., 2020). Moreover, autodock MGL tools 1.5.6 and Pymol were used to obtain PDBQT format of ligand and protein. Finally, docking results were visualized by using free source BDSV (BIOVIA Discovery Studio Visualizer (Narkhede et al., 2020). Docking was done as a blind docking (blind docking refers to the use of a grid box (40 number of points in $\mathrm{X}, \mathrm{Y}$ and $\mathrm{Z}$ dimensions with -26.283 12.599 58.966 X, Y and Z center respectively and spacing $0.375 \AA$ ) which is large enough to encompass any possible ligand-receptor complex) using ADV.

\subsection{Receptor preparation}

The Mpro of SARS-CoV 2 (PDB ID: 6LU7) (Jin et al., 2020) was used as the rigid receptor. AutoDock MGL Tools 1.5.6 was used to prepare the receptor protein. Preparation of receptor involves removal of previously attached ligand with $\mathrm{M}^{\text {pro }}$, removal of all water molecules, addition of polar hydrogen atoms, addition of kollman charges and finally to save it in PDBQT format.

\subsection{Ligand preparation}

The 3D sdf formats of all ligands were downloaded from pubchem (Kim et al., 2021). PDBQT format of all ligands were obtained by using Auto Dock MGL Tools 1.5.6. The docking was performed using exhaustiveness value of 8 , remaining parameters of the software were sustained as a default and all bonds of the ligand were allowed to move freely, taking receptor as a rigid. The final docking results were visualized through Discovery Studio Visualizer 2.5.

\subsection{ADME Analysis}

ADME (Adsorption, Distribution, Metabolism and Excretion) is important to investigate the pharmacodynamics of proposed compound. A website SWISS-ADME (Daina et al., 2017) allows the user to enter
SMILES or draw structure of proposed drug or ligand from Pubchem and offers the parameters such as lipophilicity (iLOGP, XLOGP3, WLOGP, MLOGP, SILICOS-IT, Log P0/w), drug likeness rules (Lipinski, Ghose, Veber, Egan and Muegge), water solubility-Log S (ESOL, Ali, SILICOS-IT) and Medicinal Chemistry (PAINS, Brenk, Leadlikeness, Synthetic accessibility) methods are analyzed (Daina et al., 2017). SMILES of all the ligands were obtained from Pubchem and entered into the search bar of SWISS-ADME and analyzed.

\subsection{Toxicity prediction}

Prediction of toxicology is important to predict the quantity of tolerability of molecule before being used by human or animal model. The pkCSM is an online website in which ligand can be drawn virtually or can be studied by submitting SMILES of the ligand. The website provides the details of toxicology in multiple fields such as maximum tolerable dose by human, AMES Toxicity, hERG-I and hERGII inhibitor, LOAEL, LD50, Skin Toxicity, Hepatotoxicity, T. pyriformis and Minnow toxicity (Pires et al., 2015). SMILES of ligands were searched from PubChem and submitted into online database pkCSM and toxicity mood was selected.

\section{Results and Discussion}

\subsection{Structural chemistry of ligands}

It pertinent to discuss the ligands chemistry before understanding docking results. The geometrical structures of all six ligands were optimized using density functional theory methods with B3LYP/6-311G* level of theory as implemented in Gaussian 16 suit of programs (Frisch et al., 2009). All the optimized ligands showed the planner lowest energy geometries with slightly out of plane methoxy groups. The molecular electrostatic potential (MEPs) diagrams are calculated to see the reactivities of the ligands. The MEP provides many comprehensive intuitives about the distribution of electrostatic charges on the total density surface of optimized ground state geometries of ligands as shown in Figure 1. For instance, a maximum negative region is preferred site for electrophilic attack as it is indicated with red surface. In our studied ligands, the hydroxyl and carbonyl groups are showing negative potential regions. On the other hands, the maximum positive region that is preferred site for nucleophilic attack indicated as blue color on MEP surface which are mostly acidic and/or polar hydrogen atoms of ligands. Furthermore, we have also illustrated the HOMO and LUMO orbitals of all ligands. The frontier molecular orbitals especially HOMO and LUMO play a significant role to determine the reactivity of a chemical compound. The HOMO and LUMO orbitals are shown in Figure 1 with their respective orbital energies. A careful analysis of HOMO orbitals shows that ligands Axillarin, Apigenin, Isokaempferide and Centaureidin possess somewhat uniform distributions of their valence electronic clouds as compared with other counterparts. Furthermore, we have calculated the HOMO-LUMO energies and their energy gaps $\left(\Delta_{\mathrm{HL}}\right)$ which are very crucial to define their reactivities. A graphical illustration of $\Delta_{\mathrm{HL}}$ values were given in Figure 2, which showed that axillarin ligand 


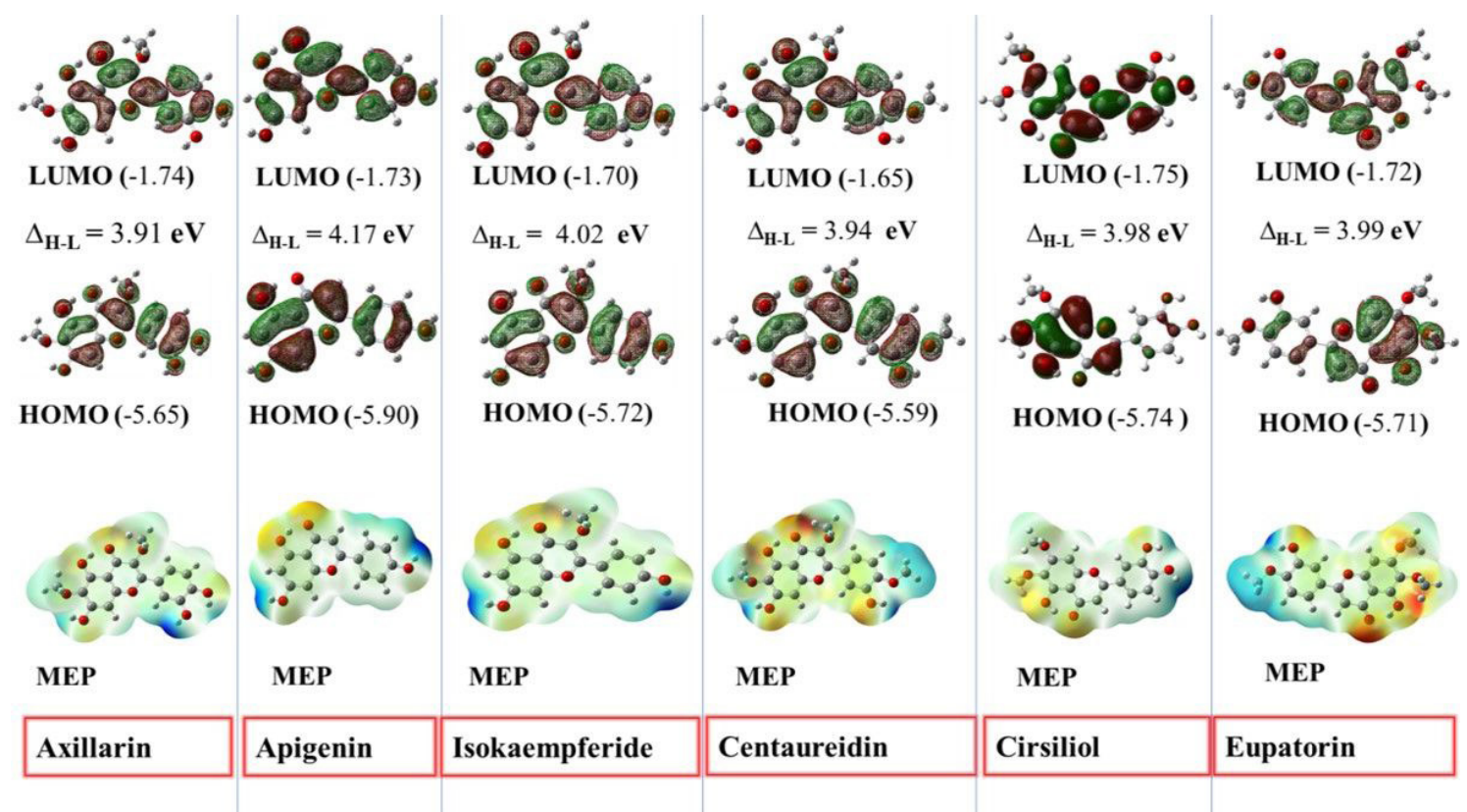

Figure 1. The 3-D plots of HOMO, LUMO and molecular electrostatic potentials (MEP) diagrams for all studied ligands as calculated at B 3 LYP/6-311G* level of theory with iso-values of \pm 0.002 a. u.

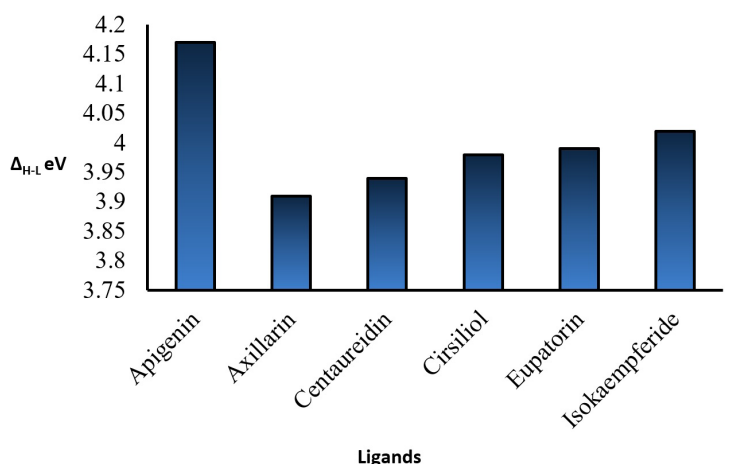

Figure 2. Comparison of $\Delta_{\mathrm{H}-\mathrm{L}}$ energy gap values for all the optimized geometries of ligands of Centaurea jacea at B3LYP/6-311G* level of theory.

possessed the lowest $\Delta_{\mathrm{HL}}$ value as compared to the other studied ligands. Usually, a lower $\Delta_{\mathrm{HL}}$ value shows higher kinetic reactivities of ligands (Aihara, 2000). Additionally, it is important to note that the number of hydroxyl, carbonyl and methoxy groups is also very vital for establishing durable interactions with receptor proteins.

\subsection{Binding energy and inhibition constant}

Docking analysis was conducted triplicate to get a clear demonstration of the mode of action of various bioactive constituents of Centaurea jacea against $\mathrm{M}^{\mathrm{pro}}$. For each constituent of Centaurea jacea nine interactions were generated and the one was selected with lowest binding energy. Our findings depicted that all the constituents of Centaurea jacea can be a potential inhibitor of $\mathrm{M}^{\text {pro }}$.
The binding pocket of $\mathrm{M}^{\text {pro }}$ comprises of two chains, Chain $A$ and $C$ which may play a pivotal role in interaction with ligand. Ligand may interact either with chain A or chain $C$ depending upon the obtainability of atoms for specific interactions (Table 1 ). Table 1 shows the binding energies, inhibition constant and interacting amino acid residues obtained from the docking of $\mathrm{M}^{\text {pro }}$ against different bioactive components (Apigenin, Axillarin, Centaureidin, Cirsiliol, Eupatorin, Isokaempferide) of Centaurea jacea. Apigenin, Axillarin, Centaureidin, Cirsiliol, Eupatorin and Isokaempferide were found as a best potential inhibitor of $\mathrm{M}^{\text {pro }}$, all of these ligands were bind with the chain $\mathrm{A}$ of $\mathrm{M}^{\mathrm{pro}}$. The binding energies acquired from the docking of $\mathrm{M}^{\text {pro }}$ with Apigenin, Axillarin, Centaureidin, Cirsiliol, Eupatorin and Isokaempferide were $-6.7 \mathrm{kcal} / \mathrm{mol},-7.4 \mathrm{kcal} / \mathrm{mol}$, $-7.0 \mathrm{kcal} / \mathrm{mol},-5.8 \mathrm{kcal} / \mathrm{mol},-6.2 \mathrm{kcal} / \mathrm{mol}$ and $-6.8 \mathrm{kcal} / \mathrm{mol}$ respectively (see Table 1 and Figure 3 ).

Inhibition constant obtained from the binding energies of $\mathrm{M}^{\text {pro }}$ in complex with Apigenin, Axillarin, Centaureidin, Cirsiliol, Eupatorin and Isokaempferide were $11.77 \mu \mathrm{M}$, $3.59 \mu \mathrm{M}, 7.08 \mu \mathrm{M}, 54.09 \mu \mathrm{M}, 27.46 \mu \mathrm{M}$ and $9.94 \mu \mathrm{M}$ respectively see table 1 . Figure 4 shows the direct relation between the binding energy and inhibition constant of all the ligands, it revealed that axillarin has lowest inhibition constant $3.59 \mu \mathrm{M}$ with lowest binding energy $-7.4 \mathrm{kcal} / \mathrm{mol}$ similarly Cirsiliol has the highest inhibition constant $54.09 \mu \mathrm{M}$ with the highest binding energy $-5.8 \mathrm{kcal} / \mathrm{mol}$.

Results of molecular docking showed the inhibition potential of bioactive constituents of Centaurea jacea ranked by their binding energies: axillarin $>$ Centaureidin $>$ Isokaempferide $>$ Apigenin $>$ Eupatorin $>$ Cirsiliol. Obtained results suggested that Axillarin gives the lowest binding energy $(-7.4 \mathrm{kcal} / \mathrm{mol})$ in complex with $\mathrm{M}^{\text {pro }}$, which is the most prominent score when compared with other docked 
Table 1. Shows the binding energies, inhibition constant ( $\mu \mathrm{mol}$ ) and amino acid residues with H-bond, Hydrophobic Interactions and Electrostatic Interactions obtained from the docking of $\mathrm{M}^{\text {pro }}$.

\begin{tabular}{|c|c|c|c|c|c|}
\hline \multirow{2}{*}{ Ligands } & \multirow{2}{*}{$\begin{array}{c}\text { Binding Energy } \\
\text { kcal/mol }\end{array}$} & \multirow{2}{*}{$\begin{array}{c}\begin{array}{c}\text { Inhibition } \\
\text { Constant }\end{array} \\
\mu \mathrm{mol}\end{array}$} & \multicolumn{3}{|c|}{ Interacting Amino Acid Residues } \\
\hline & & & H-bond & $\begin{array}{l}\text { Hydrophobic } \\
\text { Interactions }\end{array}$ & $\begin{array}{l}\text { Electrostatic } \\
\text { Interactions }\end{array}$ \\
\hline Apigenin & -6.7 & 11.77 & $\begin{array}{l}\text { LYS137 }(2.32 \AA) \\
\text { LYS137 }(2.40 \AA) \\
\text { GLU290 }(2.82 \AA)\end{array}$ & LEU286 (4.82 Å) & $\begin{array}{l}\text { ASP289 }(3.49 \AA) \\
\operatorname{ASP} 289(3.77 \AA)\end{array}$ \\
\hline Axillarin & -7.4 & 3.59 & $\begin{array}{c}\text { HIS41 }(2.91 \AA) \\
\text { CYS145 }(3.56 \AA) \\
\text { GLU166 }(2.82 \AA) \\
\text { HIS172 }(3.02 \AA) \\
\text { PHE140 }(2.22 \AA)\end{array}$ & $\begin{array}{l}\text { HIS41 }(5.90 \AA) \\
\text { HIS41 }(5.48 \AA) \\
\text { LEU141 }(4.79 \AA) \\
\text { MET49 }(3.88 \AA) \\
\text { MET165 }(4.75 \AA)\end{array}$ & - \\
\hline Centaureidin & -7.0 & 7.08 & $\begin{array}{l}\text { GLY143 (1.95 ̊) } \\
\text { GLY143 }(2.54 \AA) \\
\text { GLU166 }(2.42 \AA) \\
\text { ARG188 }(2.53 \AA) \\
\text { LEU141 }(2.86 \AA) \\
\text { THR26 }(3.59 \AA)\end{array}$ & 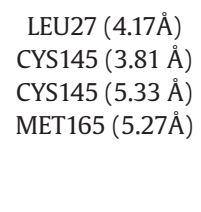 & HIS41 (4.56 Å) \\
\hline Cirsiliol & -5.8 & 54.09 & $\begin{array}{l}\text { LYS102 }(2.48 \AA) \\
\text { LYS102 }(2.24 \AA) \\
\text { LYS102 }(2.87 \AA) \\
\text { ASN151 }(2.82 \AA) \\
\text { ARG105 }(2.25 \AA) \\
\text { ASP153 }(2.10 \AA) \\
\text { SER158 }(3.24 \AA)\end{array}$ & $\begin{array}{l}\text { VAL104 }(3.49 \AA ̊) \\
\text { VAL104 }(4.28 \AA) \\
\text { VAL104 (5.39Å) }\end{array}$ & - \\
\hline Eupatorin & -6.2 & 27.46 & $\begin{array}{c}\text { LYS5 }(2.50 \AA) \\
\text { LYS137 }(2.85 \AA) \\
\text { THR199 }(2.44 \AA) \\
\text { THR199 }(2.59 \AA) \\
\text { TYR239 }(3.76 \AA) \\
\text { LEU287 }(3.67 \AA)\end{array}$ & 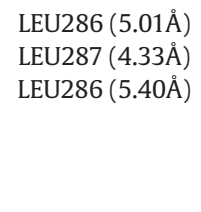 & 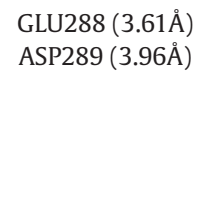 \\
\hline Isokaempferide & -6.8 & 9.94 & $\begin{array}{l}\text { LYS137 }(2.49 \AA) \\
\text { LYS137 }(2.28 \AA) \\
\text { LYS137 }(2.58 \AA) \\
\text { LYS137 }(2.70 \AA) \\
\text { GLU290 }(2.48 \AA) \\
\text { GLU288 }(2.27 \AA)\end{array}$ & $\begin{array}{l}\text { LEU286 (4.81) } \\
\text { LEU287 (5.41) }\end{array}$ & $\begin{array}{l}\text { ASP289 }(3.47 \AA) \\
\operatorname{ASP} 289(3.74 \AA)\end{array}$ \\
\hline
\end{tabular}

molecules. Axillarin gives better score than chloroquine (-6.2 kcal/mol), hydroxychloroquine $(-5.5 \mathrm{kcal} / \mathrm{mol})$ and favipiravir $(-4.2 \mathrm{kcal} / \mathrm{mol})$ (Bouchentouf and Missoum, 2020), Oseltamivir (-4.7 kcal/mol), Remdesivir (-6.5 kcal/ $\mathrm{mol})$, Ritonavir (-7.3 kcal/mol), Ribavirin $(-5.4 \mathrm{kcal} / \mathrm{mol})$ (Kitchen et al., 2004) and Galidesivir (-6.806 kcal $/ \mathrm{mol}$ ) (Chang et al., 2020) Diethylcarbamazine $(-6.9 \mathrm{kcal} / \mathrm{mol})$, Artemisinin (- $7.2 \mathrm{kcal} / \mathrm{mol}$ ) and Niclosamide (- 6.77kcal/ mol) (Das et al., 2021) when they were docked with $\mathrm{M}^{\text {pro. }}$ Even the most of the plant based compounds which were previously studied as inhibitor of $\mathrm{M}^{\text {pro }}$ have high binding affinities as compared to axillarin. They are compounds such as catechin $-7.05 \mathrm{kcal} / \mathrm{mol}$, zingerol $-6.67 \mathrm{kcal} / \mathrm{mol}$ and gingerol - $5.40 \mathrm{kcal} / \mathrm{mol}$ (Khaerunnisa et al., 2020). In addition axillarin also shows more interactions with $\mathrm{M}^{\text {pro }}$ as compared to Andrographolide who has binding energy $(-3.09 \mathrm{KJ} / \mathrm{mol})$ (Enmozhi et al., 2021) quite high as compared to axillarin which proclaims the axillarin as an attractive potential inhibitor of $\mathrm{M}^{\text {pro }}$.

\subsection{Protein-ligand interactions}

Discovery studio visualizer was used to visualize the interactions between different constituents of Centaurea jacea and $\mathrm{M}^{\text {pro }}$. Binding of ligands in different binding sites of $\mathrm{M}^{\text {pro }}$ are shown in Figure 5, protein is presented as a surface while ligand is displayed as stick model, moreover green and pink surface of the protein show acceptor and donor regions of the protein respectively Figure 5. The amino acids involve in ligand protein interactions are displayed with ligands as yellow stick model with different amino acids surrounding them. Green dashes show hydrogen bond between protein and ligand. Different amino acids involve in protein ligand interactions are displayed as stick of different colors and labeled by red color as in Figure 6 . Figure 7 shows a 2D diagram of protein ligand 


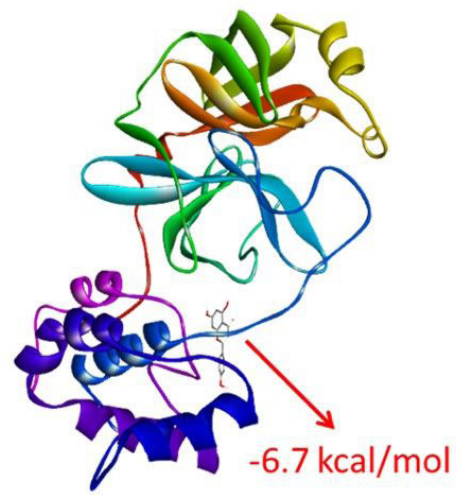

Apigenin- $\mathrm{M}^{\text {pro }}$

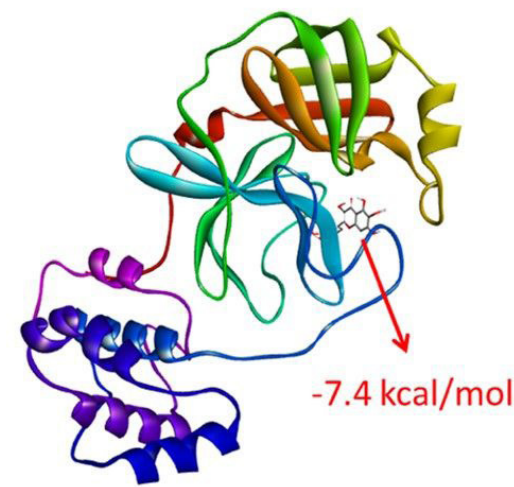

Axillarin- $\mathrm{M}^{\text {pro }}$

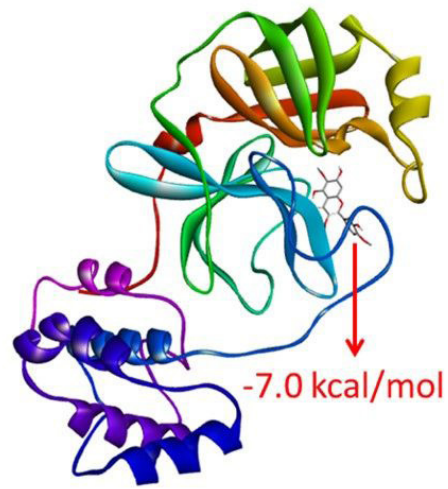

Centaureidin- $\mathrm{M}^{\text {pro }}$

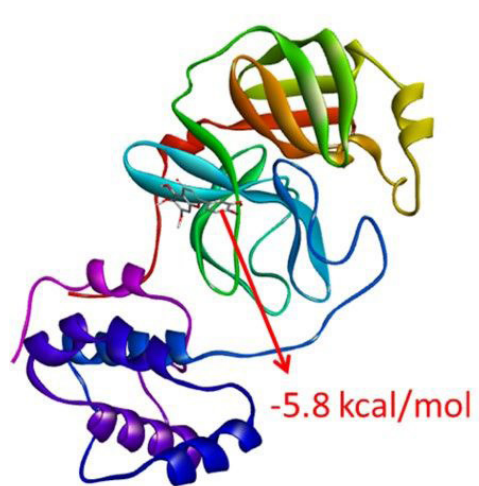

Cirsiliol- $\mathrm{M}^{\text {pro }}$

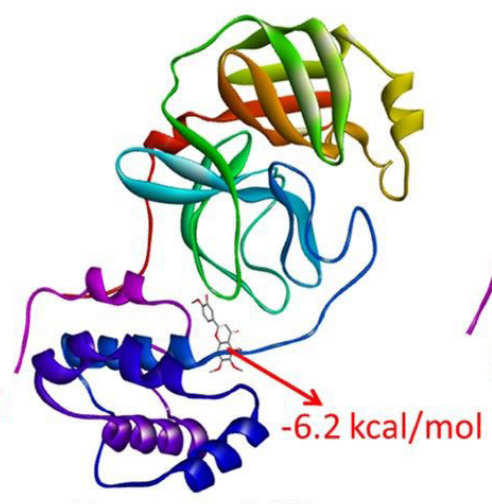

Eupatorin- $\mathrm{M}^{\text {pro }}$

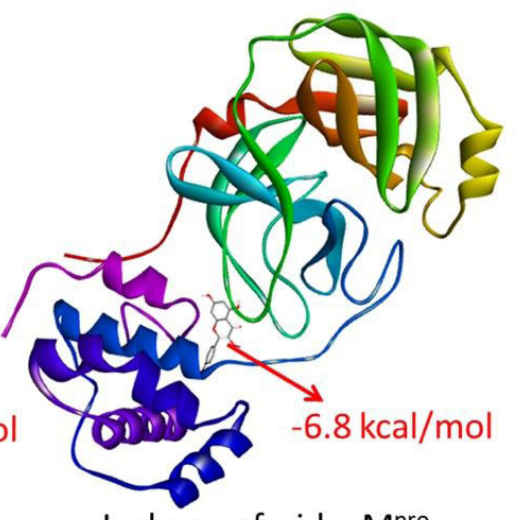

Isokaempferide- $\mathrm{M}^{\text {pro }}$

Figure 3. Binding of different bioactive components of Centaurea jacea on different binding sites of $\mathrm{M}^{\mathrm{pro}}$.

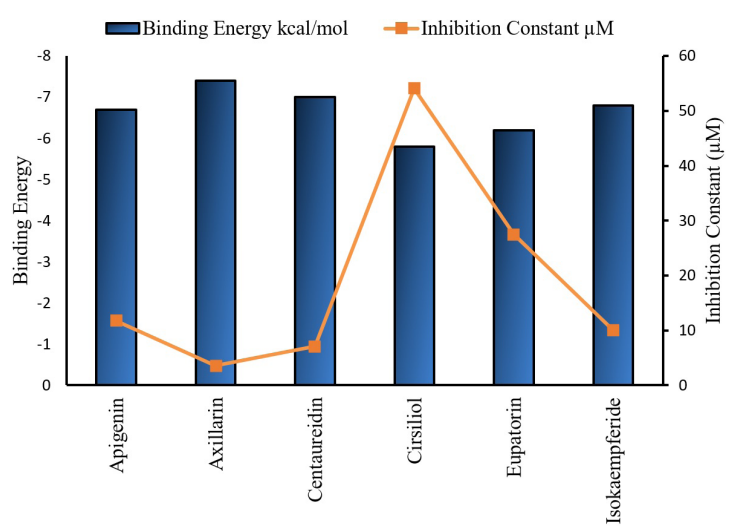

Figure 4. Showing the relationship between Binding Energy and Inhibition Constant.

complex which revealed different interactions of amino acids residues with the ligand. Circles of dark green color, light green color, purple, light and dark pink, dark orange color and red color show hydrogen bond interactions, hydrophobic interactions, electrostatic interactions and unfavorable donor-donor interactions of different protein residues with the ligand respectively.
Results of our study revealed that apigenin forms 3 hydrogen bonds with LYS137 (2.32 $\AA$ ), LYS137 (2.40 ̊) and GLU290 (2.82 A) protein residues, 1 hydrophobic interaction with LEU286 protein residue and 2 electrostatic interactions with LEU286 amino acid residue of $\mathrm{M}^{\text {pro }}$. Axillarin form 5 hydrogen bonds with HIS41 (2.91 $\AA)$, CYS145 (3.56 ̊̊), GLU166 (2.82 ̊), HIS172 (3.02 ̊) and PHE140 (2.22 $\AA$ ) protein residues and 5 hydrophobic interactions with MET49, HIS41, LEU141, MET49, and MET165 amino acid residues of $\mathrm{M}^{\text {pro }}$. The most striking property of axillarin is its interactions with CYS145 and HIS41 which are the most crucial binding sites of $\mathrm{M}^{\text {pro }}$ (Das et al., 2021). Centaureidin form 6 hydrogen bond with GLY143 (1.95 Å), GLY143 (2.54 Å), GLU166 (2.42 Å),

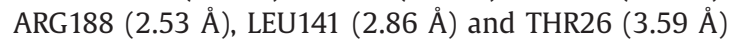
amino acid residues, 4 hydrophobic interactions with LEU27, CYS145, CYS145 and MET165 while one electrostatic interaction with HIS41 amino acid residues of $\mathrm{M}^{\text {pro. }}$. Cirsiliol potentially form 7 hydrogen bonds

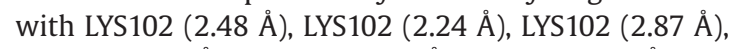
ASN151 (2.82 A), ARG105 (2.25 $), \operatorname{ASP} 153$ (2.10 $)$ and SER158 (3.24 Å) protein residues while 3 hydrophobic interactions with VAL104 protein residue of $M^{\text {pro }}$ as in Table 1 and Figure 7.

Amino acid residues LYS5 (2.50 ̊̊), LYS137 (2.85 $)$ ),

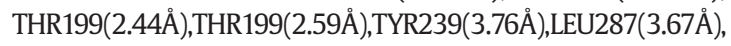




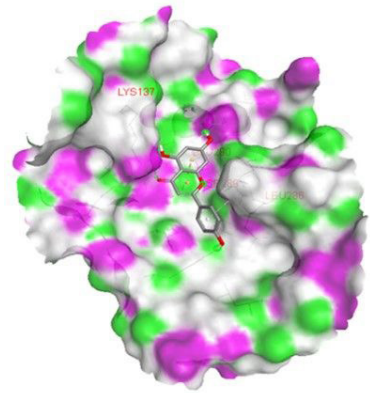

Apigenin- $\mathrm{M}^{\text {pro }}$

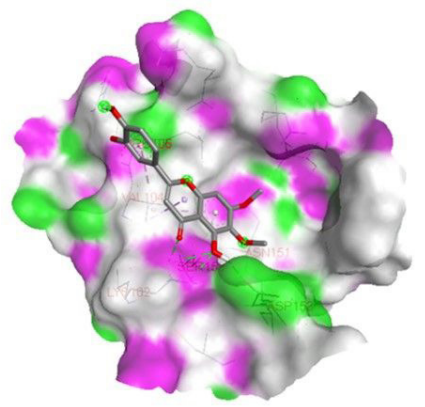

Cirsiliol- $\mathrm{M}^{\text {pro }}$

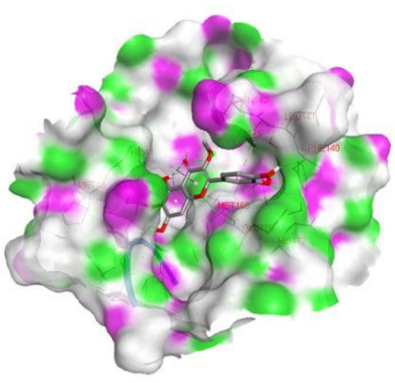

Axillarin- $\mathrm{M}^{\text {pro }}$

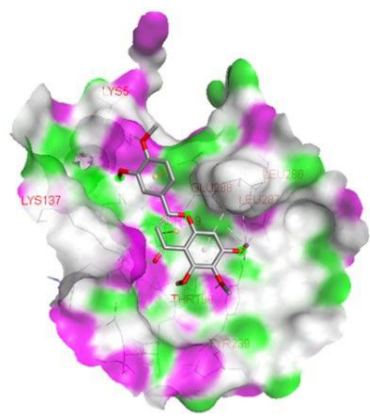

Eupatorin- $\mathrm{M}^{\text {pro }}$

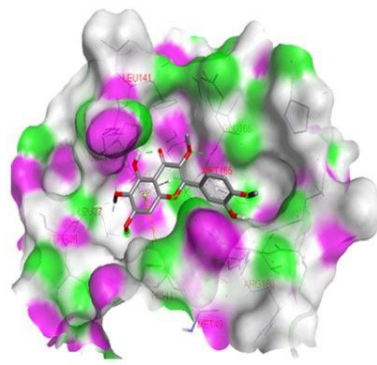

Centaureidin- $\mathrm{M}^{\text {pro }}$

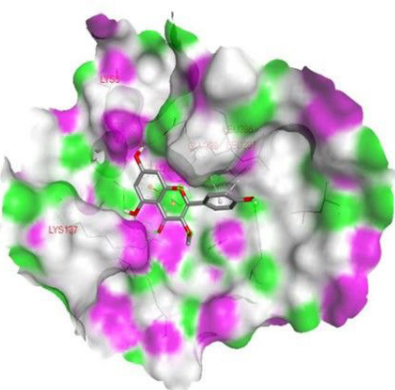

Isokaempferide- $\mathrm{M}^{\text {pro }}$

Figure 5. Surface representations of binding of various bioactive components of Centaurea jacea with different binding sites of $\mathrm{M}^{\text {pro }}$. Green and pink surface of the protein show acceptor and donor regions of the protein respectively.

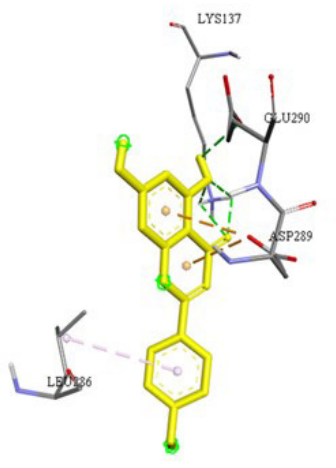

Apigenin- $\mathrm{M}^{\text {pro }}$

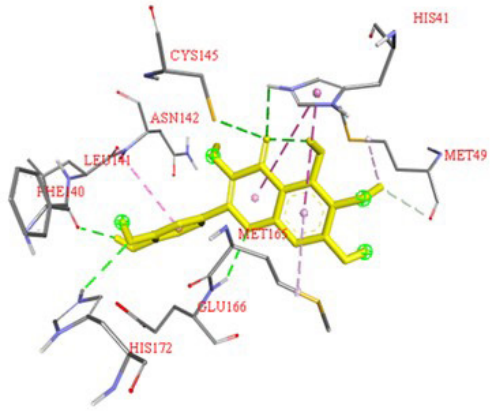

Axillarin- $\mathrm{M}^{\text {pro }}$

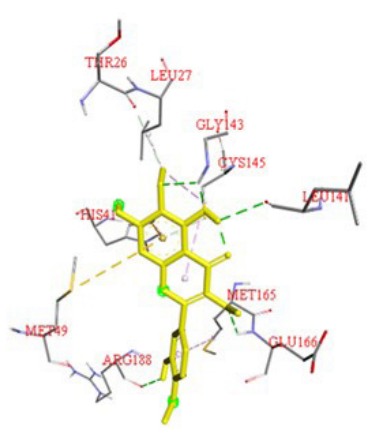

Centaureidin- $\mathrm{M}^{\text {pro }}$

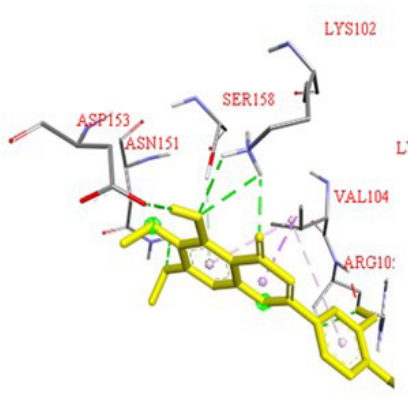

Cirsiliol- Mpro

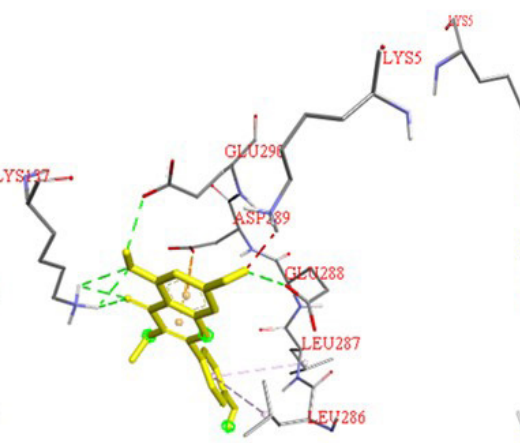

Isokaempferide- $\mathrm{M}^{\text {pro }}$

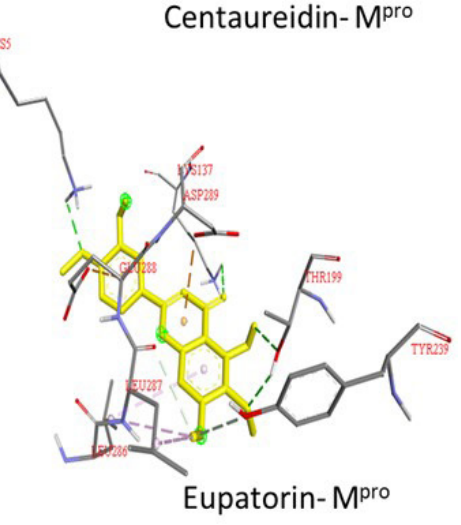

Figure 6. Interactions of various bioactive components of Centaurea jacea with the amino acid residues of $\mathrm{M}^{\text {pro }}$. Ligand is in yellow color while green lines shows hydrogen bond interaction between ligand and amino acid residues of $\mathrm{M}^{\mathrm{pro}}$. 
LEU286, LEU287, GLU288 and ASP289 participated in various interactions such as H-bond, hydrophobic interactions and electrostatic interactions with Eupatorin see 7. Figure 7 shows

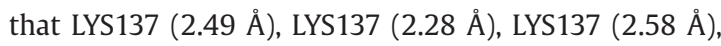
LYS137 (2.70 ̊), GLU290 (2.48 Å), GLU288 (2.27 ̊̊), LEU286,
LEU287 and ASP289 amino acid residues are responsible for the binding of Isokaempferide with $\mathrm{M}^{\text {pro }}$ of COVID-19.

Figure 8 gives a comparison of different interactions shown by a ligand with $\mathrm{M}^{\text {pro }}$. Figure 7 shows that maximum 7 hydrogen bond interactions were observed in cirsiliol$\mathrm{M}^{\text {pro }}$ complex, maximum 5 hydrophobic interactions were

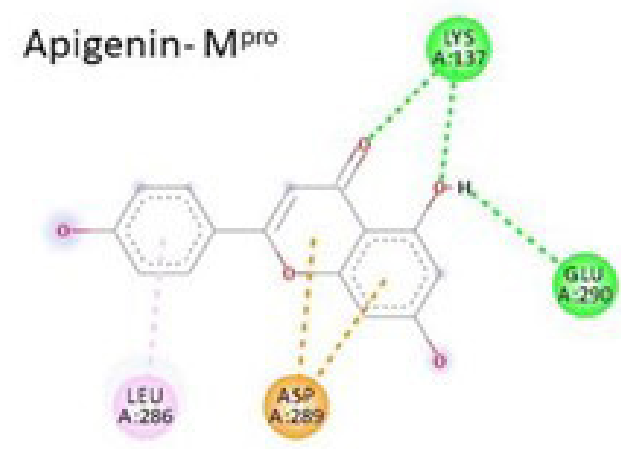

Centaureidin- $\mathrm{M}^{\text {pro }}$

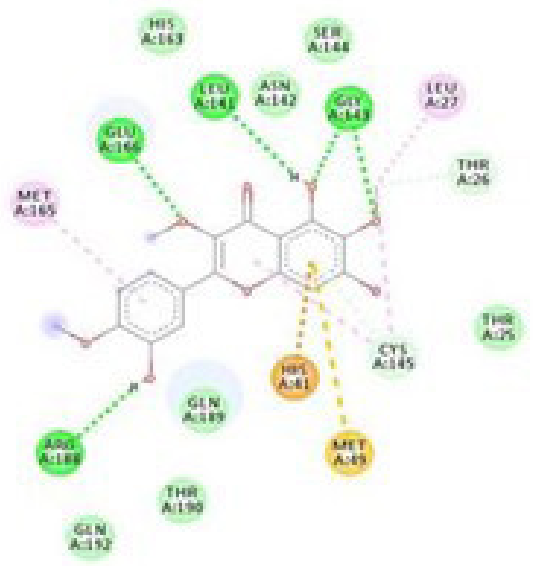

\section{Eupatorin- $\mathrm{M}^{\text {pro }}$}

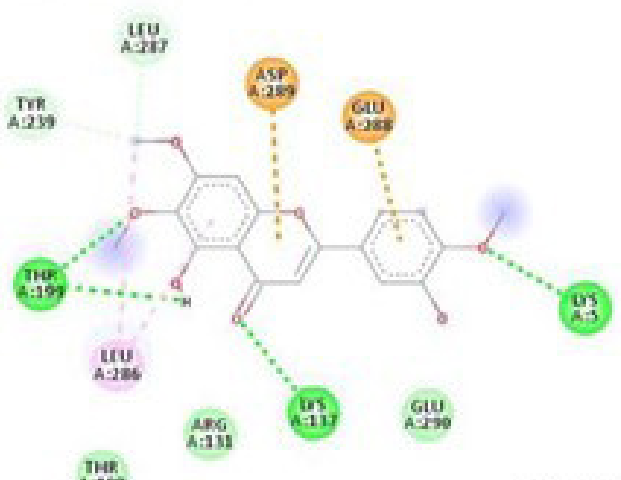

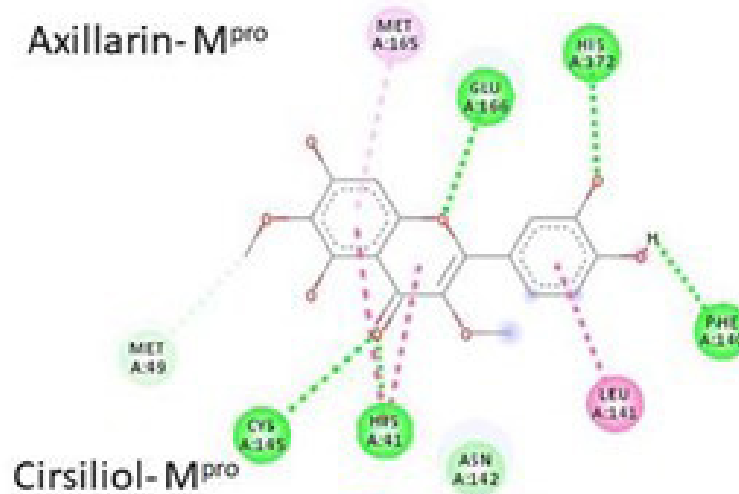
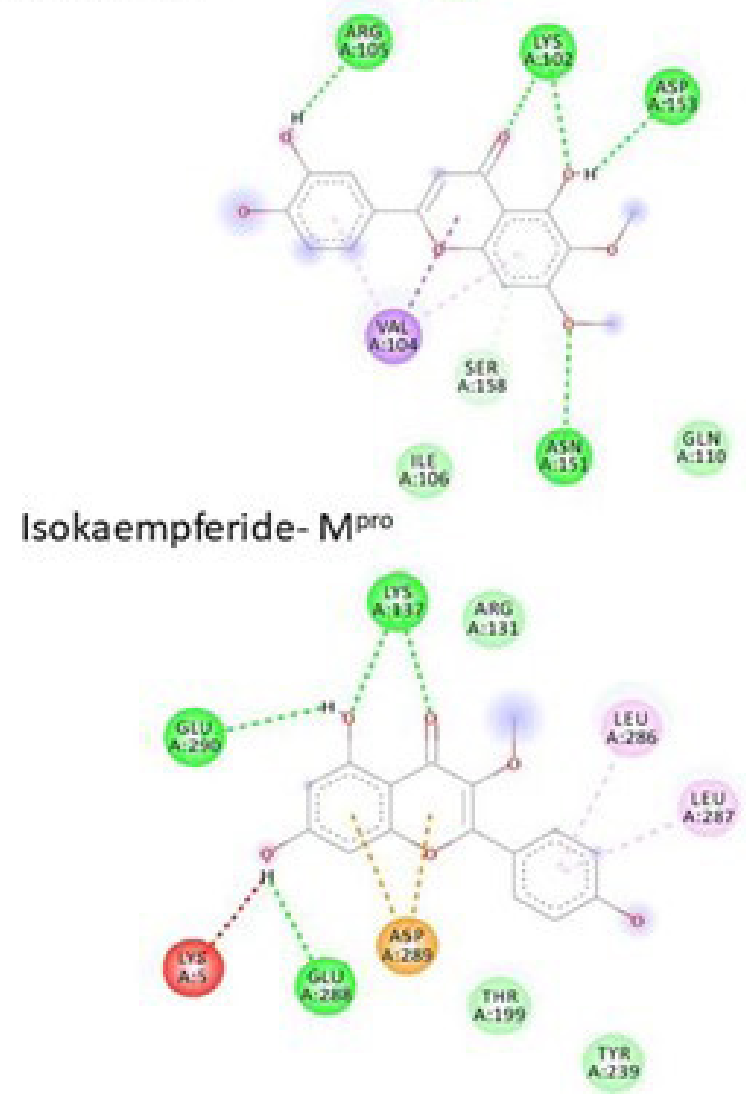

Interactions

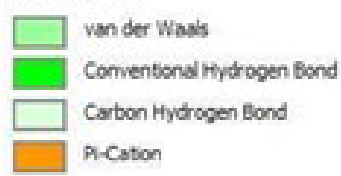

Figure 7. The 2-D diagram of various ligands and $\mathrm{M}^{\text {pro }}$ complex showing different types of interactions. 


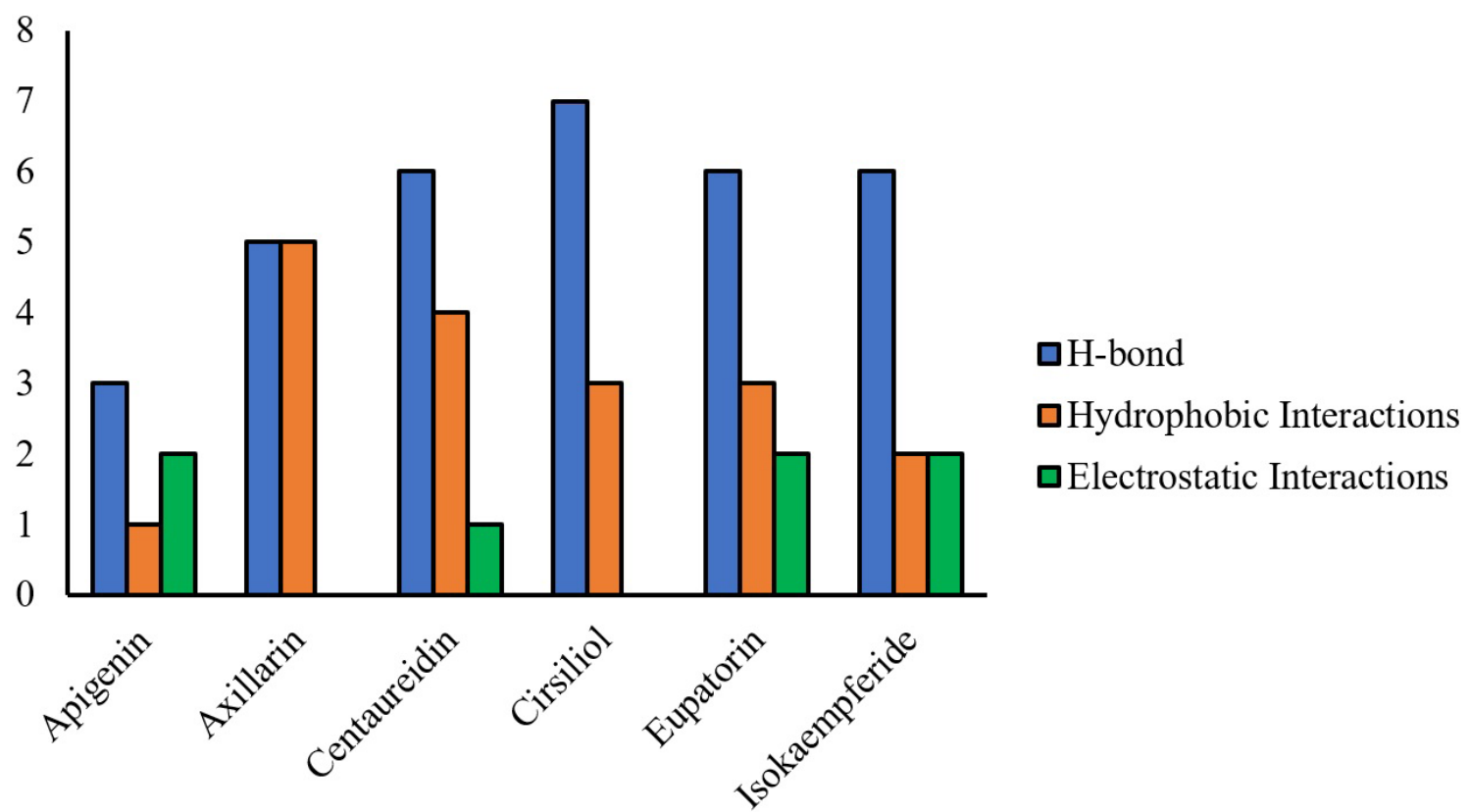

Figure 8. Comparison of different interactions shown by different ligands with $\mathrm{M}^{\text {pro }}$.

observed in axillarin- $\mathrm{M}^{\text {pro }}$ complex while Eupatorin and $\mathrm{M}^{\text {pro }}$ complex shows maximum 2 week electrostatic interactions. $\mathrm{H}$-bonds play a vital role in stabilizing the structures of all proteins due to their involvement in the secondary structure elements such as beta sheets and alpha helix. Moreover H-bond interactions are important elements for ligand binding affinity. Specificity of ligand binding is mainly determined by the number of intermolecular $\mathrm{H}$-bonds involving crucial residues present as an acceptor and donor in protein and ligand structures. These $\mathrm{H}$-bond networks played a significant role in supporting the binding affinity between ligand and protein (BitencourtFerreira et al., 2019). As Figure 8 shows that in our study most of the interactions between receptor-ligand complexes are hydrogen bond interactions so we also plot a graph between the $\mathrm{H}$-bond distances on Y-axis while protein residues according to their respective ligand was plotted on X-axis Figure 8. The shorter the bond distance will result in stronger bond between receptor-ligand complexes. Figure 9 shows that in our study H-bond between centaureidin and GLY143 residue of $\mathrm{M}^{\text {pro }}$ have minimum bond distance 1.98 Å while H-bond between eupatorin and TYR239 residue of $\mathrm{M}^{\text {pro }}$ have maximum bond distance $3.76 \AA$ A. H-bond distance between axillarin and respective $\mathrm{M}^{\text {pro }}$ residues ranges in 2.22-3.56 $\AA$. Table 1 shows the bond distance of all protein residues interacting with different ligands.

\subsection{Molecular dynamic analysis}

\subsubsection{Root Mean Square Deviation (RMSD) Study}

Among the studied complexes, we choose axillarin-Mpro complex for further molecular dynamic studies owing to its highest binding affinity and good intermolecular interactions. The NAMD (Phillips et al., 2020) with CHARMM force-field (Best et al., 2012) was used to performed minimization followed by dynamic run while trajectory, RMSD, RMSF and other analysis were done by VMD program (Humphrey et al., 1996) as developed at NIH Center for Macromolecular Modeling and Bioinformatics, Theoretical and Computational Biophysics group. The MD simulations of axillarin-M $\mathrm{M}^{\text {pro }}$ complex and $\mathrm{M}^{\text {pro }}$ protein were performed for $60 \mathrm{~ns}\left(6 \times 10^{6}\right.$ femtosecond $)$ time scale. Further details of molecular dynamic calculations can be found in the supporting information of the article. The Figure 10 shows the RMSDs of axillarin-Mpro complex and $\mathrm{M}^{\text {pro }}$ protein in overlapping fashion. A careful analysis of RMSDs indicates that the RMSD of M ${ }^{\text {pro }}$ protein (blue curve) shows some fluctuations (between 0 to $2.7 \AA$ ) for the first 0 - 7 ns and after that its RMSD becomes relatively consistent which only fluctuates between 1.5 to 2.5 A throughout the remaining time scale. While on the other hands, the RMSD of axillarin-M ${ }^{\text {pro }}$ complex shows a different behavior where at the start, it shows significant variations during $1^{\text {st }}$ nanosecond of trajectory and after that its variations remain between 1.2 to $2.7 \AA$ till 40 ns. From 40 to 50 ns, the RMSD of axillarin- $\mathrm{M}^{\text {pro }}$ complex is upset more, which finally show some convergence from 50 to $60 \mathrm{~ns}$ by constraining the fluctuations between 1.8 to $2.4 \AA$. The RMSDs analysis indicates that the docking of ligand has disturbed the RMSD of $\mathrm{M}^{\text {pro }}$ protein (blue curve) especially at the start and from 40 to 50 ns and then show reasonable stability from 50-60 ns.

\subsubsection{Root Mean Square Fluctuations (RMSF) of $M^{\text {pro }}$ residues}

The RMSF is a useful analysis to describe the local changes along the chain in protein residues. We have 


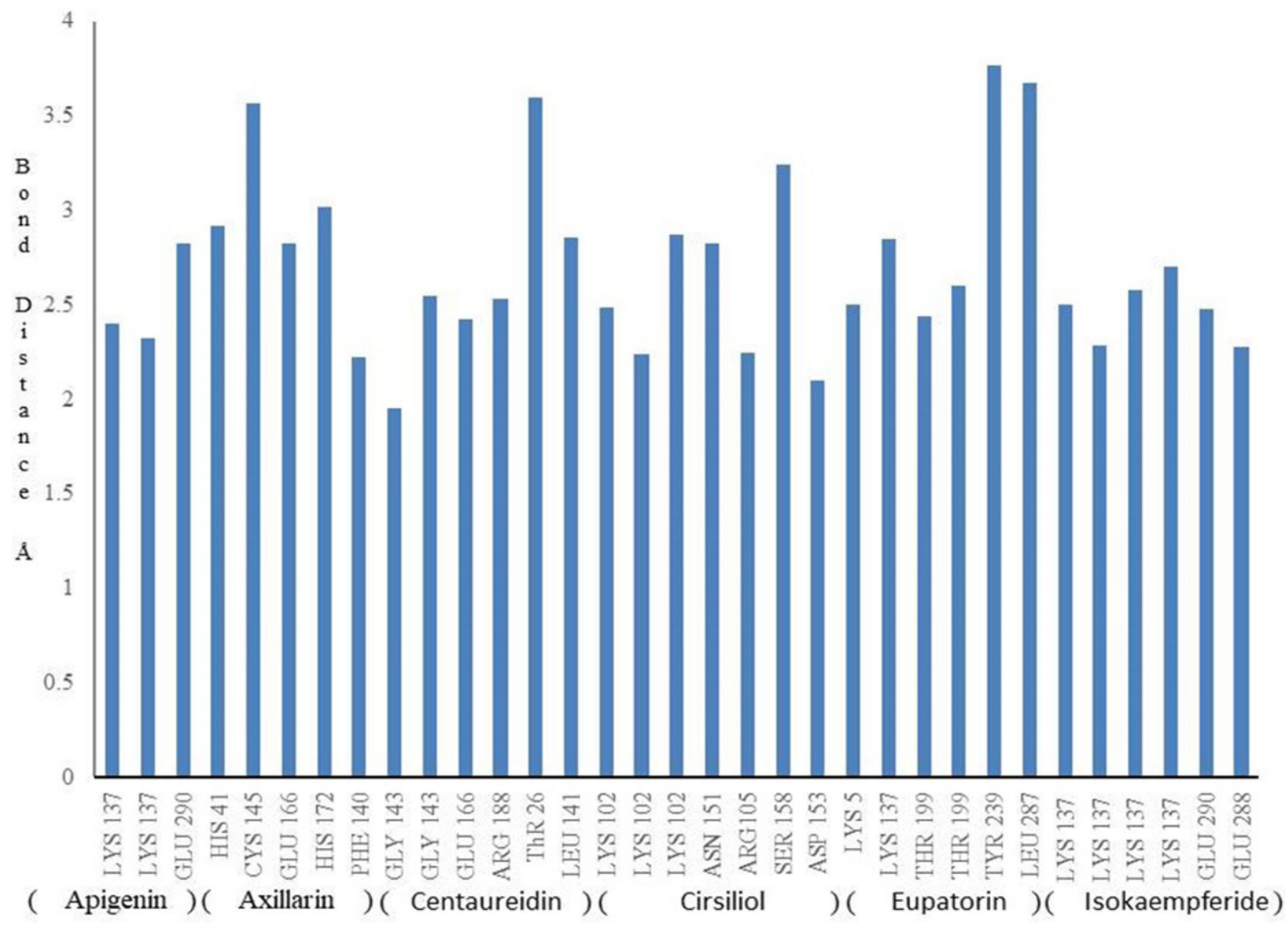

Ligands with their Respective Interacting Residues

Figure 9. Illustrating the bond distance of $\mathrm{H}$-bond between interacting residues of $\mathrm{M}^{\text {pro }}$ and respective ligand. Apigenin form $3 \mathrm{H}$-bonds from LYS137-GLU290, Axillarin form 5 H-bonds from HIS41-PHE140, centaureidin form 6 H-bonds from GLY143-LEU141, cirsiliol form 7 H-bonds from LYS102-ASP153, eupatorin form 5 H-bonds from LYS5-LEU287 and isokaempferide form 6 H-bonds from LYS137GLU288 of Mpro.

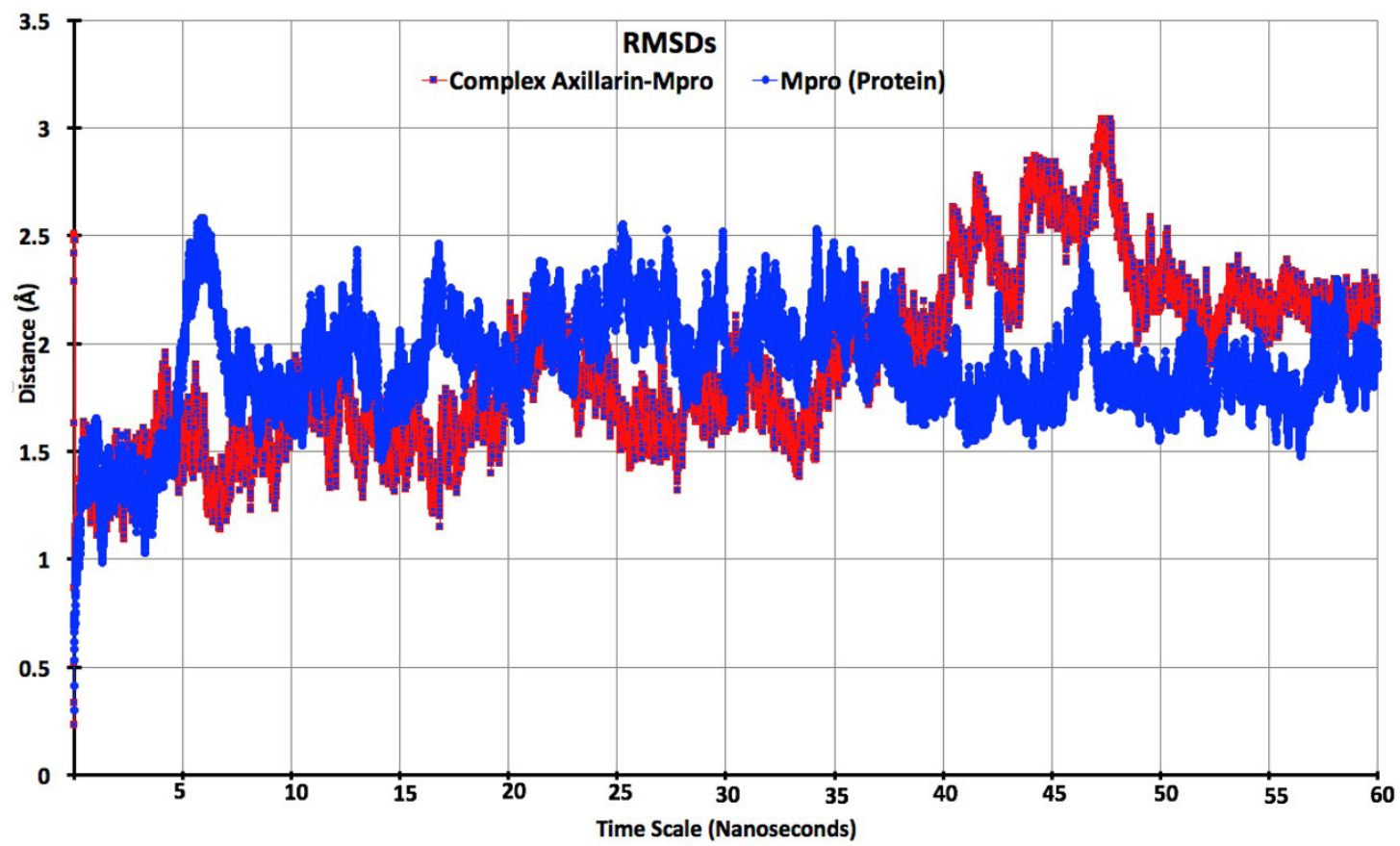

Figure 10. The calculated RMSDs of axillarin- $\mathrm{M}^{\text {pro }}$ complex and $\mathrm{M}^{\text {pro }}$ protein over a period of $60 \mathrm{~ns}\left(6 \times 10^{6}\right.$ femtosecond) time scale. 
calculated and plotted the RMSFs of $\mathrm{M}^{\text {pro }}$ protein and RMSF of $\mathrm{M}^{\text {pro }}$ while it is docked with axillarin to see the effect of docking as shown in Figure 11. In the RMSF graphs, the peak areas indicate the residues which fluctuates the most during the simulation. It is commonly observed that tail areas with $\mathrm{C}$ - and $\mathrm{N}$-terminals show larger fluctuations as compared to the other parts. The overlapping of RMSFs of axillarin- $\mathrm{M}^{\text {pro }}$ complex and $\mathrm{M}^{\text {pro }}$ protein shows that the initial three residues show maximum fluctuations both in $\mathrm{M}^{\mathrm{pro}}$ protein and its complex with axillarin, which is owing to their primary structural configurations in $\mathrm{M}^{\mathrm{pro}}$ protein. A careful analysis of both RMSFs illustrates that there is reasonable stability after docking of axillarin with $\mathrm{M}^{\text {pro }}$ protein because overall no abnormal and/or significant fluctuations are seen in RMSFs of $\mathrm{M}^{\text {pro }}$ protein and axillarin-Mpro complex (see the red curve).

\subsection{Predicted ADME (absorption, distribution, metabolism and excretion) properties of ligands}

To predict the drug likeness, the ADME properties for various constituents of Centaurea jacea were calculated (Table 2). Molar refractivity of our best docked compound axallrin is 89. The LogP values of ADME analysis for axillarin represented its lipophilic nature with consensuses LogP values 2.30. Water solubility value of ADME analysis for axillarin is -3.81 which suggested that axalllrin is moderately soluble in water. Axillarin is considered as a good candidate of drugs for oral administration because it is highly absorbable in GIT (gastrointestinal tract). Axillarin clearly fulfilled the Lipinski's rule of five (Lipinski, 2004).
Synthetic accessibility for axallrin is found to be 3.46. ADME properties for rest of the compounds are given in Table 2 .

Molar refractivity of the drug compounds endorses that the compound is permeable for specific membranes and can persist even in the midst of weak or strong solventsolvent and solute-solvent interactions. Lipophilicity of a compound tells us about the oral, intestinal and sublingual absorption of the compound. Water solubility values of a compound shows that the compound is freely soluble in water or not (Enmozhi et al., 2021).

\subsection{Toxicity prediction}

Toxicity prediction analysis for different constituents of Centaurea jacea was carried out by using an online website, pKCSM (http://biosig.unimelb.edu.au/pkcsm/ prediction). Results of the analysis shown in Table 3, all of the components of Centaurea jacea don't show AMES toxicity, don't have ability to induce hepatotoxicity and do not cause skin sensitivity. Maximum tolerable dose for human of our best docked compound axillarin is about $0.506 \log \mathrm{mg} / \mathrm{kg} /$ day, acute oral rat toxicity (LD50) and chronic oral rat toxicity is $2.35 \mathrm{~mol} / \mathrm{kg}$ and $2.50 \mathrm{log} \mathrm{mg} /$ kg_bw/day respectively. Moreover, $0.30 \mathrm{log} \mathrm{mg} / \mathrm{L}$ and $2.979 \log \mathrm{mM}$ of axillarin can cause T. pyriformis and Minnow Toxicity, respectively. Molecular docking, ADME analysis and toxicity prediction results of axillarin and $\mathrm{M}^{\text {pro }}$ complex are appreciable in silico, therefore, in vitro, in vivo and clinical studies should be done for the development of novel antiviral drug against novel SARS CoV-2.

Aforementioned results of molecular docking show the axillarin as an ideal inhibitor of $\mathrm{M}^{\text {pro }}$ especially interaction

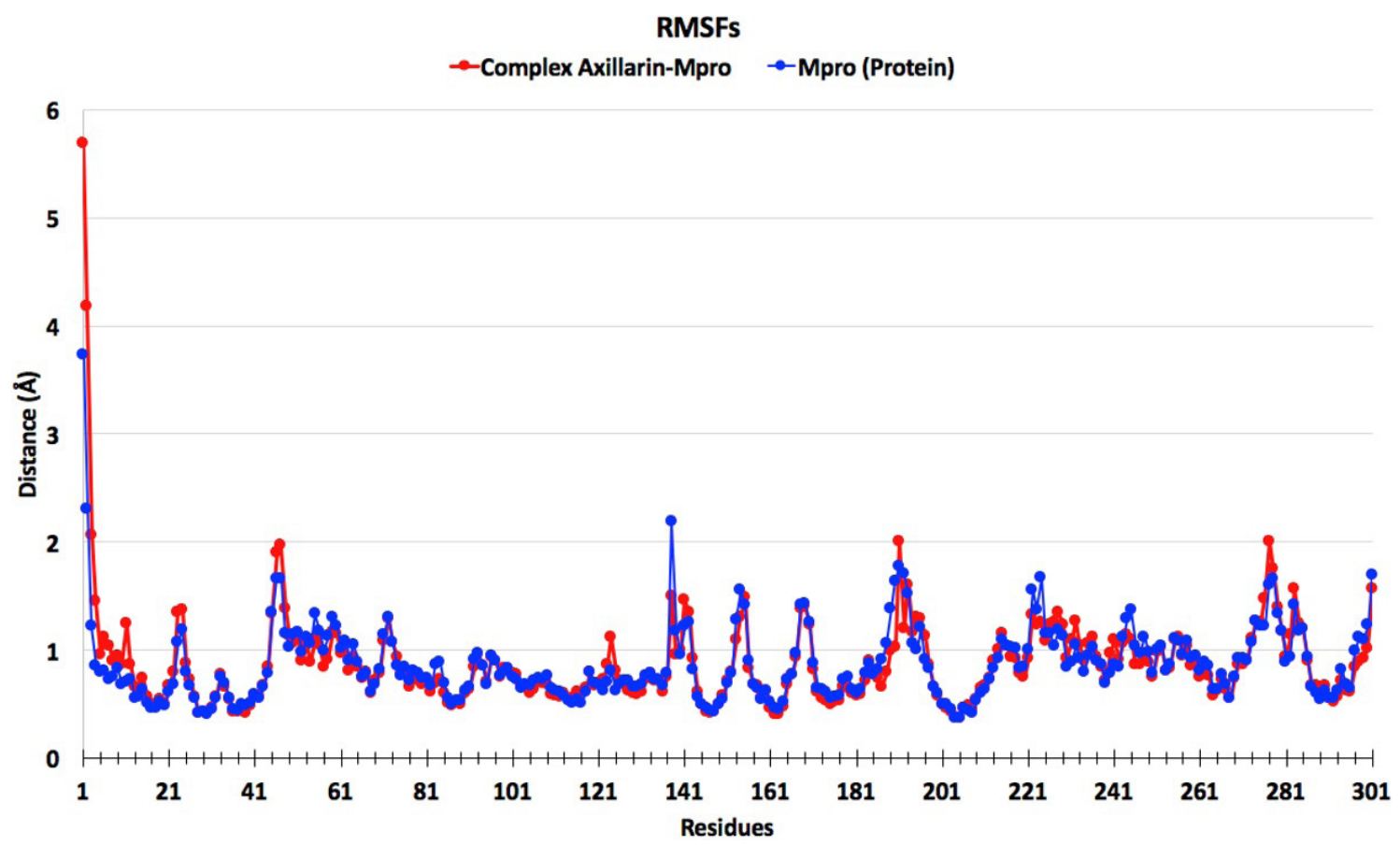

Figure 11. The RMSF of $\mathrm{M}^{\text {pro }}$ protein (blue) and axillarin- $\mathrm{M}^{\text {pro }}$ complex (red). 
Table 2. ADME properties of different studied bioactive components of Centaurea jacea.

\begin{tabular}{|c|c|c|c|c|c|c|}
\hline Parameters & Apigenin & Axillarin & Centaureidin & Cirsiliol & Eupatorin & Isokaempferide \\
\hline $\begin{array}{l}\text { Molecular } \\
\text { Formula }\end{array}$ & $\mathrm{C}_{15} \mathrm{H}_{10} \mathrm{O}_{5}$ & $\mathrm{C}_{17} \mathrm{H}_{14} \mathrm{O}_{8}$ & $\mathrm{C}_{18} \mathrm{H}_{16} \mathrm{O}_{8}$ & $\mathrm{C}_{17} \mathrm{H}_{14} \mathrm{O}_{7}$ & $\mathrm{C}_{18} \mathrm{H}_{16} \mathrm{O}_{7}$ & $\mathrm{C}_{16} \mathrm{H}_{12} \mathrm{O}_{6}$ \\
\hline $\begin{array}{l}\text { Molecular } \\
\text { Weight }\end{array}$ & 270.24 & 346.3 & 360.3 & 330.29 & 344.3 & 300.26 \\
\hline $\begin{array}{l}\text { Molar } \\
\text { Refractivity }\end{array}$ & 73.99 & 89 & 93.47 & 86.97 & 91.44 & 80.48 \\
\hline $\begin{array}{l}\text { Lipophilicity } \\
\text { (WLogP) }\end{array}$ & 2.58 & 2.3 & 2.6 & 2.59 & 2.9 & 2.59 \\
\hline $\begin{array}{l}\text { Consensus Log } \\
\text { Po/w }\end{array}$ & 2.11 & 1.73 & 2.14 & 2.13 & 2.53 & 1.94 \\
\hline Water Solubility & -3.94 & -3.81 & -4.02 & -4.12 & -4.33 & -3.51 \\
\hline GI Absorption & High & High & High & High & High & High \\
\hline $\begin{array}{l}\text { Log Kp (skin } \\
\text { permeation) }\end{array}$ & -5.8 & -6.67 & -6.52 & -6.14 & -5.99 & -6.56 \\
\hline Lipinski rule & Yes & Yes & Yes & Yes & Yes & Yes \\
\hline Leadlikeness & Yes & Yes & Yes & Yes & Yes & Yes \\
\hline $\begin{array}{l}\text { Synthetic } \\
\text { accessibility }\end{array}$ & 2.96 & 3.46 & 3.57 & 3.32 & 3.43 & 3.2 \\
\hline
\end{tabular}

Units: Molecular Weight $=\mathrm{g} / \mathrm{mol}: \log \mathrm{Kp}($ skin permeation $)=\mathrm{cm} / \mathrm{s}$.

Table 3. Shows toxicity prediction for various constituents of Centaurea jacea.

\begin{tabular}{|c|c|c|c|c|c|c|}
\hline Ligand & Apigenin & Axillarin & Centaureidin & Cirsiliol & Eupatorin & Isokaempferide \\
\hline AMES toxicity & No & No & No & No & No & No \\
\hline $\begin{array}{l}\text { Max. Tolerated } \\
\text { dose (human) }\end{array}$ & 0.328 & 0.506 & 0.594 & 0.379 & 0.262 & 0.34 \\
\hline $\begin{array}{l}\text { Oral Rat Acute } \\
\text { Toxicity }\end{array}$ & 2.45 & 2.35 & 2.286 & 2.387 & 2.246 & 2.395 \\
\hline $\begin{array}{l}\text { Oral Rat Chronic } \\
\text { Toxicity }\end{array}$ & 2.29 & 2.5 & 2.224 & 2.399 & 1.928 & 1.704 \\
\hline Hepatotoxicity & No & No & No & No & No & No \\
\hline Skin Sensation & No & No & No & No & No & No \\
\hline $\begin{array}{l}\text { T. pyriformis } \\
\text { toxicity }\end{array}$ & 0.38 & 0.3 & 0.319 & 0.348 & 0.346 & 0.314 \\
\hline Minnow Toxicity & 2.43 & 2.979 & 1.86 & 1.78 & 1.691 & 1.539 \\
\hline
\end{tabular}

Units: Max. Tolerated dose (human) = log mg $/ \mathrm{kg} /$ day; Oral Rat Acute Toxicity $\left(\right.$ LD50)= mol $/ \mathrm{kg}$; Oral Rat Chronic Toxicity (LOEL)= log mg $/ \mathrm{kg} \_b w /$ day; T. pyriformis toxicity $=\log \mathrm{mg} / \mathrm{L}$; Minnow Toxicity $=\log \mathrm{mM}$.

of axillarin with the most important catalytic residues of $\mathrm{M}^{\text {pro }}$ proves it as a potential inhibitor of $\mathrm{M}^{\text {pro. }}$. Moreover, druglikness and toxicity prediction analysis also revealed the use of axillarin as a safe and specific antiviral drug against SARS-CoV-2. As it's an in-silico study, therefore in vivo and in vitro studies should be done in future for the development of axillarin as an anti-SARS-CoV-2 drug.

\section{Conclusions}

Thus, we have successfully performed molecular docking and molecular dynamic studies to explore the potential of different compounds as potential inhibitor for COVID-19 M $\mathrm{M}^{\text {pro }}$ from Centaurea jacea. All the studied compounds such as apigenin, axillarin, Centaureidin, Cirsiliol, Eupatorin and Isokaempferide, could strongly bind to the binding site of SARS-CoV-2 main protease with binding energies $-6.7 \mathrm{kcal} / \mathrm{mol},-7.4 \mathrm{kcal} / \mathrm{mol},-7.0 \mathrm{kcal} / \mathrm{mol}$, $-5.8 \mathrm{kcal} / \mathrm{mol},-6.2 \mathrm{kcal} / \mathrm{mol}$ and $-6.8 \mathrm{kcal} / \mathrm{mol}$ respectively. Inhibition constant obtained from the binding energies of $\mathrm{M}^{\text {pro }}$ in complex with Apigenin, Axillarin, Centaureidin, Cirsiliol, Eupatorin and Isokaempferide were $11.77 \mu \mathrm{M}$, $3.59 \mu \mathrm{M}, 7.08 \mu \mathrm{M}, 54.09 \mu \mathrm{M}, 27.46 \mu \mathrm{M}$ and $9.94 \mu \mathrm{M}$ respectively. Our results proved that studied bioactive constituents of Centaurea jacea strongly bind with the 
different binding sites of $\mathrm{M}^{\text {pro }}$ of SARS-CoV-2, which is essential for proteolytic maturation of SARS-CoV-2. Among all the docked compounds, the axillarin was found to be the most effective inhibitor of $\mathrm{M}^{\text {pro }}$ based on its lowest binding affinity of $-7.4 \mathrm{kcal} \mid \mathrm{mol}$, inhibition constant $3.59 \mu \mathrm{M}$ and its maximum hydrophobic, electrostatic and hydrogen bond interactions. Furthermore, the molecular dynamic calculations also showed significant insights into the binding effects of axillarin with $\mathrm{M}^{\text {pro }}$ of SARS-CoV-2. The RMSD and RMSF calculation indicates the stability and dynamics of complex in aqueous environment. Besides this, the results of quantum chemical study for the ligands also show that axillarin is most reactive among all docked compounds due to lowest $\Delta_{\mathrm{HL}}$. In addition to molecular docking study druglikness prediction shows that axillarin clearly follow the Lipinski rule of drug likeness, moreover toxicity prediction also proves it as a safe drug for human. Results of Molecular docking, druglikeness and toxicity prediction for all the studied compounds of C. jacea particularly for axillarin encourage further in vivo, in vitro and clinical studies to prove its inhibitory effect against $\mathrm{M}^{\text {pro }}$ of SARS-CoV-2 of axillarin.

\section{Acknowledgements}

The authors extend their appreciation to the Institute of Research and Consulting Studies at King Khalid University for supporting this research through grant number 2-N-20/22 and the support of Research Center for Advanced Materials Science is highly acknowledged. For computer time, this research used the resources of the Supercomputing Laboratory at King Abdullah University of Science and Technology (KAUST) in Thuwal, Saudi Arabia.

\section{References}

ADEM, S., EYUPOGLU, V., SARFRAZ, I., RASUL, A. and ALI, M., 2020. Identification of potent COVID-19 main protease (Mpro) inhibitors from natural polyphenols: an in silico strategy unveils a hope against CORONA. Preprints, pp. 1-16. http:// dx.doi.org/10.20944/preprints202003.0333.v1.

AIHARA, J.I., 2000. Correlation found between the HOMO-LUMO energy separation and the chemical reactivity at the most reactive site for isolated-pentagon isomers of fullerenes. Physical Chemistry Chemical Physics, vol. 2, no. 14, pp. 3121-3125. http:// dx.doi.org/10.1039/b002601h.

BAKR, R.O., MOHAMED, S.A.E.H. and AYOUB, N., 2016. Phenolic profile of Centaurea aegyptiaca L. growing in Egypt and its cytotoxic and antiviral activities. African Journal of Traditional, Complementary, and Alternative Medicines, vol. 13, no. 6, pp. 135143. http://dx.doi.org/10.21010/ajtcam.v13i6.19. PMid:28480370.

BALUNAS, M.J. and KINGHORN, A.D., 2005. Drug discovery from medicinal plants. Life Sciences, vol. 78, no. 5, pp. 431-441. http:// dx.doi.org/10.1016/j.lfs.2005.09.012. PMid:16198377.

BEST, R.B., ZHU, X., SHIM, J., LOPES, P.E., MITTAL, J., FEIG, M. and MACKERELL JUNIOR, A.D., 2012. Optimization of the additive CHARMM all-atom protein force field targeting improved sampling of the backbone $\phi, \psi$ and side-chain $\chi 1$ and $\chi 2$ dihedral angles. Journal of Chemical Theory and Computation, vol. 8 , no. 9, pp. 3257-3273. http://dx.doi.org/10.1021/ct300400x. PMid:23341755.
BITENCOURT-FERREIRA, G., VEIT-ACOSTA, M. and DE AZEVEDO, W.F., 2019. Hydrogen bonds in protein-ligand complexes. Docking screens for drug discovery. USA: Springer.

BOUCHENTOUF, S., and MISSOUM, N., 2020. Identification of compounds from nigella sativa as new potential inhibitors of 2019 Novel Coronasvirus (Covid-19): molecular docking study. ChemRxiv, pp. 1-12. Preprint. http://dx.doi.org/10.20944/ preprints202004.0079.v1.

CAO, B., WANG, Y., WEN, D., LIU, W., WANG, J., FAN, G., RUAN, L., SONG, B., CAI, Y., WEI, M., LI, X., XIA, J., CHEN, N., XIANG, J., YU, T., BAI, T., XIE, X., ZHANG, L., LI, C., YUAN, Y., CHEN, H., LI, H., HUANG, H., TU, S., GONG, F., LIU, Y., WEI, Y., DONG, C., ZHOU, F., GU, X., XU, J., LIU, Z., ZHANG, Y., LI, H., SHANG, L., WANG, K., LI, K., ZHOU, X., DONG, X., QU, Z., LU, S., HU, X., RUAN, S., LUO, S., WU, J., PENG, L., CHENG, F., PAN, L., ZOU, J., JIA, C., WANG, J., LIU, X., WANG, S., WU, X., GE, Q., HE, J., ZHAN, H., QIU, F., GUO, L., HUANG, C., JAKI, T., HAYDEN, F.G., HORBY, P.W., ZHANG, D. and WANG, C., 2020. A trial of lopinavir-ritonavir in adults hospitalized with severe Covid-19. The New England Journal of Medicine, vol. 382, no. 19, pp. 1787-1799. http://dx.doi. org/10.1056/NEJMoa2001282. PMid:32187464.

CHAKRABORTY, P., 2018. Herbal genomics as tools for dissecting new metabolic pathways of unexplored medicinal plants and drug discovery. Biochimie Open, vol. 6, pp. 9-16. https://doi. org/10.1016/j.biopen.2017.12.003.

CHAN, J.F.W., TO, K.K.W., TSE, H., JIN, D.Y. and YUEN, K.Y., 2013. Interspecies transmission and emergence of novel viruses: lessons from bats and birds. Trends in Microbiology, vol. 21, no. 10, pp. 544-555. http://dx.doi.org/10.1016/j.tim.2013.05.005. PMid:23770275.

CHANG, Y.C., TUNG, Y.A., LEE, K.H., CHEN, T.F., HSIAO, Y.C., CHANG, H.C., HSIEH, T.T., SU, C.H., WANG, S.S., YU, J.Y., SHIH, S., LIN, Y., LIN, Y., TU, Y.E., HSU, C., JUAN, H., TUNG, C., and CHEN, C., 2020. Potential therapeutic agents for COVID-19 based on the analysis of protease and RNA polymerase docking. Preprints, pp. 1-11. https://doi.org/10.20944/preprints202002.0242.v2.

CHIARELLO, A. G., 1995. Density and habitat use of primates at an Atlantic Forest Reserve of Southeastern Brazhji. Revista Brasileira de Biologia, vol. 55, no. 1, pp. 105-110. PMid:7569145.

DAI, W., ZHANG, B., JIANG, X.M., SU, H., LI, J., ZHAO, Y., XIE, X., JIN, Z., PENG, J., LIU, F., LI, C., LI, Y., BAI, F., WANG, H., CHENG, X., CEN, X., HU, S., YANG, X., WANG, J., LIU, X., XIAO, G., JIANG, H., RAO, Z., ZHANG, L.K., XU, Y., YANG, H. and LIU, H., 2020. Structure-based design of antiviral drug candidates targeting the SARS-CoV-2 main protease. Science, vol. 368 , no. 6497 , pp. 1331-1335. http://dx.doi.org/10.1126/science.abb4489. PMid:32321856.

DAINA, A., MICHIELIN, O. and ZOETE, V., 2017. SwissADME: a free web tool to evaluate pharmacokinetics, drug-likeness and medicinal chemistry friendliness of small molecules. Scientific Reports, vol. 7, no. 1, pp. 42717. http://dx.doi.org/10.1038/ srep42717. PMid:28256516.

DAS, S., SARMAH, S., LYNDEM, S. and SINGHA ROY, A., 2021. An investigation into the identification of potential inhibitors of SARS-CoV-2 main protease using molecular docking study. Journal of Biomolecular Structure \& Dynamics, vol. 39, no. 9, pp. 3347. http://dx.doi.org/10.1080/07391102.2020.1763201 PMid:32362245.

ENMOZHI, S.K., RAJA, K., SEBASTINE, I. and JOSEPH, J., 2021. Andrographolide as a potential inhibitor of SARS-CoV-2 main protease: an in-silico approach. Journal of Biomolecular Structure E'Dynamics, vol. 39, no. 9, pp. 3092-3098. http://dx.doi.org/10 .1080/07391102.2020.1760136. PMid:32329419. 
FORGO, P., ZUPKÓ, I., MOLNÁR, J., VASAS, A., DOMBI, G. and HOHMANN, J., 2012. Bioactivity-guided isolation of antiproliferative compounds from Centaurea jacea L. Fitoterapia, vol. 83, no. 5, pp. 921-925. http://dx.doi.org/10.1016/j. fitote.2012.04.006. PMid:22537643.

FRISCH, M., TRUCKS, G., SCHLEGEL, H., SCUSERIA, G., ROBB, M., CHEESEMAN, J., SCALMANI, G., BARONE, V., MENNUCCI, B. and PETERSSON, G., 2009. Gaussian 09, rev. Wallingford: Gaussian Inc.

GERTSCH, J., 2011. Botanical drugs, synergy, and network pharmacology: forth and back to intelligent mixtures. Planta Medica, vol. 77, no. 11, pp. 1086-1098. http://dx.doi. org/10.1055/s-0030-1270904. PMid:21412698.

HAYDEN, F.G., TURNER, R.B., GWALTNEY, J.M., CHI-BURRIS, K., GERSTEN, M., HSYU, P., PATICK, A.K., SMITH 3RD, G.J. and ZALMAN, L.S., 2003. Phase II, randomized, double-blind, placebo-controlled studies of ruprintrivir nasal spray 2-percent suspension for prevention and treatment of experimentally induced rhinovirus colds in healthy volunteers. Antimicrobial Agents and Chemotherapy, vol. 47, no. 12, pp. 3907-3916. http:// dx.doi.org/10.1128/AAC.47.12.3907-3916.2003. PMid:14638501.

HUMPHREY, W., DALKE, A., and SCHULTEN, K., 1996. VMD: Visual molecular dynamics. Journal of Molecular Graphics, vol. 14, no. 1, pp. 33-38. http://dx.doi.org/10.1016/0263-7855(96)00018-5.

JIN, Z., DU, X., XU, Y., DENG, Y., LIU, M., ZHAO, Y., ZHANG, B., LI, X., ZHANG, L. and PENG, C., 2020. Structure of Mpro from SARSCoV-2 and discovery of its inhibitors. Nature, vol. 582, pp. 289-293. https://doi.org/10.1038/s41586-020-2223-y.

JORGENSEN, W.L., 2004. The many roles of computation in drug discovery. Science, vol. 303, no. 5665, pp. 1813-1818. http:// dx.doi.org/10.1126/science.1096361. PMid:15031495.

KHAERUNNISA, S., KURNIAWAN, H., AWALUDDIN, R., SUHARTATI, S., and SOETJIPTO, S., 2020. Potential inhibitor of COVID-19 main protease (Mpro) from several medicinal plant compounds by molecular docking study. Preprints, vol. 20944, pp. 1-14. http:// dx.doi.org/10.20944/preprints202003.0226.v1.

KIM, S., CHEN, J., CHENG, T., GINDULYTE, A., HE, J., HE, S., LI, Q., SHOEMAKER, B.A., THIESSEN, P.A., YU, B., ZASLAVSKY, L., ZHANG, J. and BOLTON, E.E., 2021. PubChem in 2021: new data content and improved web interfaces. Nucleic Acids Research, vol. 49, no. D1, pp. D1388-D1395. https://doi.org/10.1093/ nar/gkaa971.

KITCHEN, D.B., DECORNEZ, H., FURR, J.R. and BAJORATH, J., 2004. Docking and scoring in virtual screening for drug discovery: methods and applications. Nature Reviews. Drug Discovery, vol. 3, no. 11, pp. 935-949. http://dx.doi.org/10.1038/nrd1549. PMid:15520816.

KUMAR, S., KUMAR, G. and SHUKLA, I.C., 2020. Substituted phenothiazines: synthesis and in silico evaluation of D4 dopamine receptor inhibition. SN Applied Sciences, vol. 2, no. 7, pp. 1-11. http://dx.doi.org/10.1007/s42452-020-3067-7.

LIPINSKI, C., 2004. Lead- and drug-like compounds: the rule-offive revolution. Drug Discovery Today. Technologies, vol. 1, no. 4, pp. 337-341. http://dx.doi.org/10.1016/j.ddtec.2004.11.007. PMid:24981612.

LU, R., ZHAO, X., LI, J., NIU, P., YANG, B., WU, H., WANG, W., SONG, H., HUANG, B., ZHU, N., BI, Y., MA, X., ZHAN, F., WANG, L., HU, T., ZHOU, H., HU, Z., ZHOU, W., ZHAO, L., CHEN, J., MENG, Y., WANG, J., LIN, Y., YUAN, J., XIE, Z., MA, J., LIU, W.J., WANG, D., XU, W., HOLMES, E.C., GAO, G.F., WU, G., CHEN, W., SHI, W. and TAN, W., 2020. Genomic characterisation and epidemiology of 2019 novel coronavirus: implications for virus origins and receptor binding. Lancet, vol. 395, no. 10224, pp. 565-574. http:// dx.doi.org/10.1016/S0140-6736(20)30251-8. PMid:32007145.
MALIK, Y.S., SIRCAR, S., BHAT, S., SHARUN, K., DHAMA, K., DADAR, M., TIWARI, R. and CHAICUMPA, W., 2020. Emerging novel coronavirus (2019-nCoV): current scenario, evolutionary perspective based on genome analysis and recent developments. The Veterinary Quarterly, vol. 40, no. 1, pp. 68-76. http://dx.doi. org/10.1080/01652176.2020.1727993. PMid:32036774.

MCCONKEY, B.J., SOBOLEV, V. and EDELMAN, M., 2002 [viewed 15 January 2021]. The performance of current methods in ligandprotein docking. Current Science [online], vol. 88, no. 7, pp. 845856. Available from: https://www.jstor.org/stable/24107087.

MURGUEITIO, M.S., BERMUDEZ, M., MORTIER, J. and WOLBER, G., 2012. In silico virtual screening approaches for anti-viral drug discovery. Drug Discovery Today. Technologies, vol. 9, no. 3, pp. e219-e225. http://dx.doi.org/10.1016/j.ddtec.2012.07.009. PMid:24990575.

NARKHEDE, R. R., CHEKE, R. S., AMBHORE, J. P., and SHINDE, S.D., 2020. The molecular docking study of potential drug candidates showing anti-COVID-19 activity by exploring of therapeutic targets of SARS-CoV-2. Screening, vol. 4, no. 3, pp. 185-195. http://dx.doi.org/10.14744/ejmo.2020.31503.

PERLMAN, S. and NETLAND, J., 2009. Coronaviruses post-SARS: update on replication and pathogenesis. Nature Reviews. Microbiology, vol. 7, no. 6, pp. 439-450. http://dx.doi.org/10.1038/ nrmicro2147. PMid: 19430490.

PHILLIPS, J.C., HARDY, D.J., MAIA, J.D., STONE, J.E., RIBEIRO, J.V., BERNARDI, R.C., BUCH, R., FIORIN, G., HÉNIN, J., JIANG, W., MCGREEVY, R., MELO, M.C.R., RADAK, B.K., SKEEL, R.D., SINGHAROY, A., WANG, Y., ROUX, B., AKSIMENTIEV, A., LUTHEY-SCHULTEN, Z., KALÉ, L.V., SCHULTEN, K., CHIPOT, C. and TAJKHORSHID, E., 2020. Scalable molecular dynamics on CPU and GPU architectures with NAMD. The Journal of Chemical Physics, vol. 153, no. 4, pp. 044130. http://dx.doi. org/10.1063/5.0014475. PMid:32752662.

PIRES, D.E., BLUNDELL, T.L. and ASCHER, D.B., 2015. pkCSM: predicting small-molecule pharmacokinetic and toxicity properties using graph-based signatures. Journal of Medicinal Chemistry, vol. 58, no. 9, pp. 4066-4072. http://dx.doi. org/10.1021/acs.jmedchem.5b00104. PMid:25860834.

POLITEO, O., CAREV, I. and VELJACA, A., 2019. Phytochemical composition, antiradical and anticholinesterase potentials of Centaurea alba and Centaurea jacea volatile oils. Croatica Chemica Acta, vol.92, no. 1, pp. 11-17. http://dx.doi.org/10.5562/cca3458.

RAMAJAYAM, R., TAN, K.-P. and LIANG, P.H., 2011. Recent development of $3 C$ and $3 C L$ protease inhibitors for anticoronavirus and anti-picornavirus drug discovery. Biochemical Society Transactions, vol. 39, no. 5, pp. 1371-1375. http://dx.doi. org/10.1042/BST0391371.

REN, Z., YAN, L., ZHANG, N., GUO, Y., YANG, C., LOU, Z., and RAO, Z., 2013. The newly emerged SARS-like coronavirus HCoV-EMC also has an" Achilles' heel": current effective inhibitor targeting a 3C-like protease. Protein Andcell, vol. 4, no. 4, pp. 248. http:// dx.doi.org/10.1007/s13238-013-2841-3.

SALEHI, B., SHAROPOV, F., MARTORELL, M., RAJKOVIC, J., ADEMILUYI, A.O., SHARIFI-RAD, M., FOKOU, P.V.T., MARTINS, N., IRITI, M. and SHARIFI-RAD, J., 2018. Phytochemicals in Helicobacter pylori infections: what are we doing now? International Journal of Molecular Sciences, vol. 19, no. 8, pp. 2361. http://dx.doi. org/10.3390/ijms19082361. PMid:30103451.

SHARIFI-RAD, M., ROBERTS, T.H., MATTHEWS, K.R., BEZERRA, C.F., MORAIS-BRAGA, M.F.B., COUTINHO, H.D., SHAROPOV, F., SALEHI, B., YOUSAF, Z., SHARIFI-RAD, M., DEL MAR CONTRERAS, M., VARONI, E.M., VERMA, D.R., IRITI, M. and SHARIFI-RAD, J., 2018. Ethnobotany of the genus Taraxacum: phytochemicals and 
antimicrobial activity. Phytotherapy Research, vol. 32, no. 11, pp. 2131-2145. http://dx.doi.org/10.1002/ptr.6157. PMid:30039597.

WORLD HEALTH ORGANIZATION - WHO, 2021 [viewed 03 April 2021]. WHO dashboard: Coronavirus disease (COVID-19) pandemic [online]. Retrived from: https://www.who.int/emergencies/ diseases/novel-coronavirus-2019.

WU, F., ZHAO, S., YU, B., CHEN, Y.M., WANG, W., SONG, Z.G., HU, Y., TAO, Z.W., TIAN, J.H., PEI, Y.Y., YUAN, M.L., ZHANG, Y.L., DAI, F.H., LIU, Y., WANG, Q.M., ZHENG, J.J., XU, L., HOLMES, E.C. and ZHANG, Y.Z., 2020. A new coronavirus associated with human respiratory disease in China. Nature, vol. 579, no. 7798 , pp. 265-269. http://dx.doi.org/10.1038/s41586-020-2008-3. PMid:32015508

XU, Z., PENG, C., SHI, Y., ZHU, Z., MU, K., WANG, X. and ZHU, W., 2020. Nelfinavir was predicted to be a potential inhibitor of 2019-nCov main protease by an integrative approach combining homology modelling, molecular docking and binding free energy calculation. bioRxiv. http://dx.doi.org/10.1101/2020.01.27.921627.

YAN, X., QI, M., LI, P., ZHAN, Y., and SHAO, H., 2017. Apigenin in cancer therapy: anti-cancer effects and mechanisms of action.
Cell and Bioscience, vol. 7, no. 1, pp. 50. https://doi.org/10.1186/ s13578-017-0179-X.

YANG, H., XIE, W., XUE, X., YANG, K., MA, J., LIANG, W., ZHAO, Q., ZHOU, Z., PEI, D., ZIEBUHR, J., HILGENFELD, R., YUEN, K.Y., WONG, L., GAO, G., CHEN, S., CHEN, Z., MA, D., BARTLAM, M. and RAO, Z., 2005. Design of wide-spectrum inhibitors targeting coronavirus main proteases. PLoS Biology, vol. 3, no. 11, pp. e324. http://dx.doi.org/10.1371/journal.pbio.0030324. PMid: 16128623.

ZHANG, L., LIN, D., SUN, X., CURTH, U., DROSTEN, C., SAUERHERING, L., BECKER, S., ROX, K. and HILGENFELD, R., 2020. Crystal structure of SARS-CoV-2 main protease provides a basis for design of improved $\alpha$-ketoamide inhibitors. Science, vol. 368, no. 6489, pp. 409-412. http://dx.doi.org/10.1126/science. abb3405. PMid:32198291.

ZHOU, P., YANG, X.-L., WANG, X.-G., HU, B., ZHANG, L., ZHANG, W., SI, H.-R., ZHU, Y., LI, B., and HUANG, C.L., 2020. A pneumonia outbreak associated with a new coronavirus of probable bat origin. Nature, vol. 579, no. 7798, pp. 270-273. https://doi. org/10.1038/s41586-020-2012-7. 